\title{
Marine Microbiological Enzymes: Studies with Multiple Strategies and Prospects
}

\author{
Yan Wang, Qinghao Song and Xiao-Hua Zhang * \\ College of Marine Life Sciences, Ocean University of China, Qingdao 266003, China;

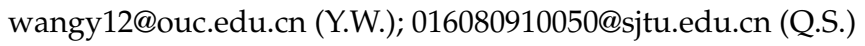 \\ * Correspondence: xhzhang@ouc.edu.cn; Tel./Fax: +86-532-82032767 \\ Academic Editor: Se-Kwon Kim \\ Received: 12 July 2016; Accepted: 14 September 2016; Published: 22 September 2016
}

\begin{abstract}
Marine microorganisms produce a series of promising enzymes that have been widely used or are potentially valuable for our daily life. Both classic and newly developed biochemistry technologies have been broadly used to study marine and terrestrial microbiological enzymes. In this brief review, we provide a research update and prospects regarding regulatory mechanisms and related strategies of acyl-homoserine lactones (AHL) lactonase, which is an important but largely unexplored enzyme. We also detail the status and catalytic mechanism of the main types of polysaccharide-degrading enzymes that broadly exist among marine microorganisms but have been poorly explored. In order to facilitate understanding, the regulatory and synthetic biology strategies of terrestrial microorganisms are also mentioned in comparison. We anticipate that this review will provide an outline of multiple strategies for promising marine microbial enzymes and open new avenues for the exploration, engineering and application of various enzymes.
\end{abstract}

Keywords: AHL lactonase; polysaccharide-degrading enzymes; marine microorganism

\section{Introduction}

Microorganisms produce series of enzymes [1-3]. Given the complicated diversity and ease of large-scale fermentation, microorganisms are widely used in the exploration of enzyme resources. In recent decades, bacteria and fungi from the terrestrial environment have served as the most important and best-studied sources for promising industrial enzymes and secondary metabolites. Recent technological developments have made it easier to utilize marine resources, especially from the deep sea $[4,5]$. The ocean occupies greater than $70 \%$ of total surface of the earth, thus serving as a habitat for numerous microorganisms with vast diversity. The special environmental conditions, involving low temperature, low light, high pressure and high salinity, give marine residents multiple novel characteristic features, which have been attracting increasing attention from marine biologists. Correspondingly, these organisms also produce various novel enzymes and secondary metabolites, some of which have already been used as food additives and potential drugs [6-8]. For example, various PKS (polyketide synthase) and NRPS (non-ribosomal peptide synthetase) enzymes responsible for producing secondary metabolites have been identified in marine bacteria, particularly Streptomyces, and fungi in recent years [9-12]. However, compared to terrestrial resources, marine microbial resources, e.g., amylase and alginate lyase, are largely unexplored, although this pool of marine resources is huge. Moreover, the regulatory mechanisms of promising genes and signaling pathway cascades of marine microorganisms are also largely unknown.

In this review, we provide a brief description of two types of promising marine enzymes: acyl-homoserine lactones (AHL) lactonase and polysaccharide-degrading enzymes. We will present the recent research progress regarding these enzymes and discuss potential strategies for further 
studies. Using well-studied terrestrial microorganisms as references, we hope to open new avenues of exploration, engineering and regulatory mechanisms of marine enzymes.

\section{AHL Lactonase}

\subsection{Introduction}

Quorum sensing is a population-dependent reaction for microorganisms that occurs via the up/down-regulation of downstream gene expression [13]. The process is also essential for biofilm formation and the secretion of virulence factors, especially in pathogenic bacteria, and causes a series of bacterial diseases [14]. Correspondingly, quorum-quenching technology is an environmentally friendly strategy for disease control $[15,16]$. AHL lactonase, which degrades molecular $N$-acyl homoserine lactone (AHL) signals, is one of the two types of enzymes involved in quorum quenching (Figure 1). AHL lactonase can open the lactonic ring, and the ring-open molecule is ineffective and cannot reorganize downstream receptor proteins. Several AHL lactonases have been isolated and well-studied in recent years (Table 1). The first reported and well-studied AHL lactonase is AiiA, which inhibits the pathogenic bacterium Erwinia carotovora and other plant-related pathogenic bacteria with considerably high activities $[17,18]$. AiiA is one type of metalloprotein that contains the highly conserved amino acid sequence HXDH-H-D, which serves as a zinc-binding site $[17,18]$. The conserved sequence is also present in a series of AHL lactonase family members and is essential for normal protein activity [19]. Previous studies revealed that the combination of a yeast strain overexpressing AiiA and the pathogenic bacterium Aeromonas hydrophila significantly decreased the death rate of cultivated carp [20,21]. In addition, AiiA, AiiB, AttM, AhlD, QsdA, AiiM and AidH were cloned and characterized from soil Bacillus, Agrobacterium, Arthrobacter, Rhodococcus, Microbacterium and Ochrobactrum, respectively [22-28]. All of these AHL lactonases were from terrestrial bacteria (Figure 2).

Table 1. Properties of well-studied acyl-homoserine lactones (AHL) lactonase.

\begin{tabular}{|c|c|c|c|c|c|c|c|}
\hline $\begin{array}{c}\text { QQ } \\
\text { Enzyme }\end{array}$ & $\begin{array}{l}\text { Length } \\
\text { (aa) }\end{array}$ & Predictable Domains & $\begin{array}{l}\text { Signal } \\
\text { Peptide }\end{array}$ & $\begin{array}{c}\text { Host } \\
\text { Organisms }\end{array}$ & Origin & Structure & References \\
\hline AiiA & 231aa & $\begin{array}{l}\text { Beta-lactamase family } \\
\qquad(15-216)\end{array}$ & No signal & Bacillus & terrestrial & $3 \mathrm{DHB}$ & [18] \\
\hline AiiB & $276 a a$ & $\begin{array}{l}\text { Beta-lactamase family } \\
\qquad(42-259)\end{array}$ & No signal & Agrobacterium & terrestrial & unknown & {$[22]$} \\
\hline AttM & $295 \mathrm{aa}$ & $\begin{array}{l}\text { Beta-lactamase family } \\
\text { (78-282) }\end{array}$ & $1-17$ & Agrobacterium & terrestrial & unknown & [25] \\
\hline QsdA & 323aа & $\begin{array}{l}\text { Phosphotriesterase family } \\
(11-322)\end{array}$ & No signal & Rhodococcus & terrestrial & unknown & [24] \\
\hline AidH & 279aа & $\begin{array}{c}\text { Alpha/beta hydrolase } \\
\text { (25-147) }\end{array}$ & No signal & Ochrobactrum & terrestrial & unknown & {$[27,28]$} \\
\hline GKL & $330 \mathrm{aa}$ & $\begin{array}{l}\text { Phosphotriesterase family } \\
\qquad(16-329)\end{array}$ & No signal & Geobacillus & terrestrial & unknown & [26] \\
\hline MomL & 293aa & $\begin{array}{l}\text { Beta-lactamase family } \\
\text { (72-277) }\end{array}$ & $1-21$ & Muricauda & oceanic & unknown & [29] \\
\hline QsdH & 968aa & $\begin{array}{c}\text { AcrB/AcrD/AcrF family } \\
\text { (182-964) }\end{array}$ & $1-23$ & Pseudoalteromonas & oceanic & unknown & {$[30]$} \\
\hline
\end{tabular}

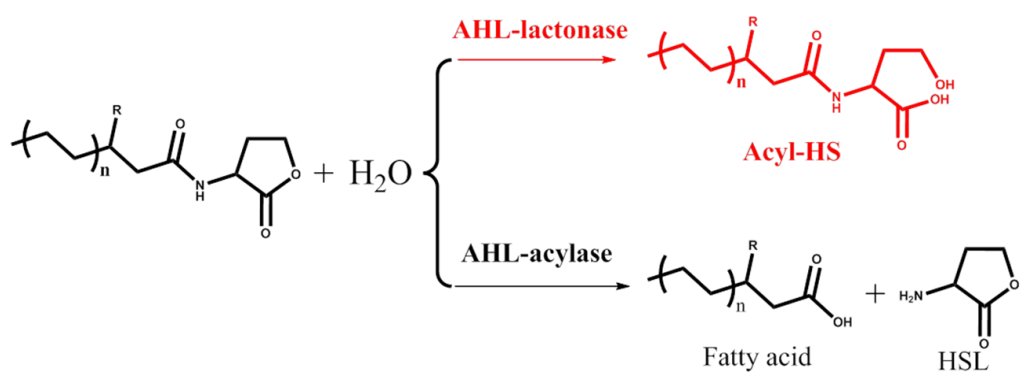

Figure 1. Catalytic mechanism of quorum quenching enzymes. 


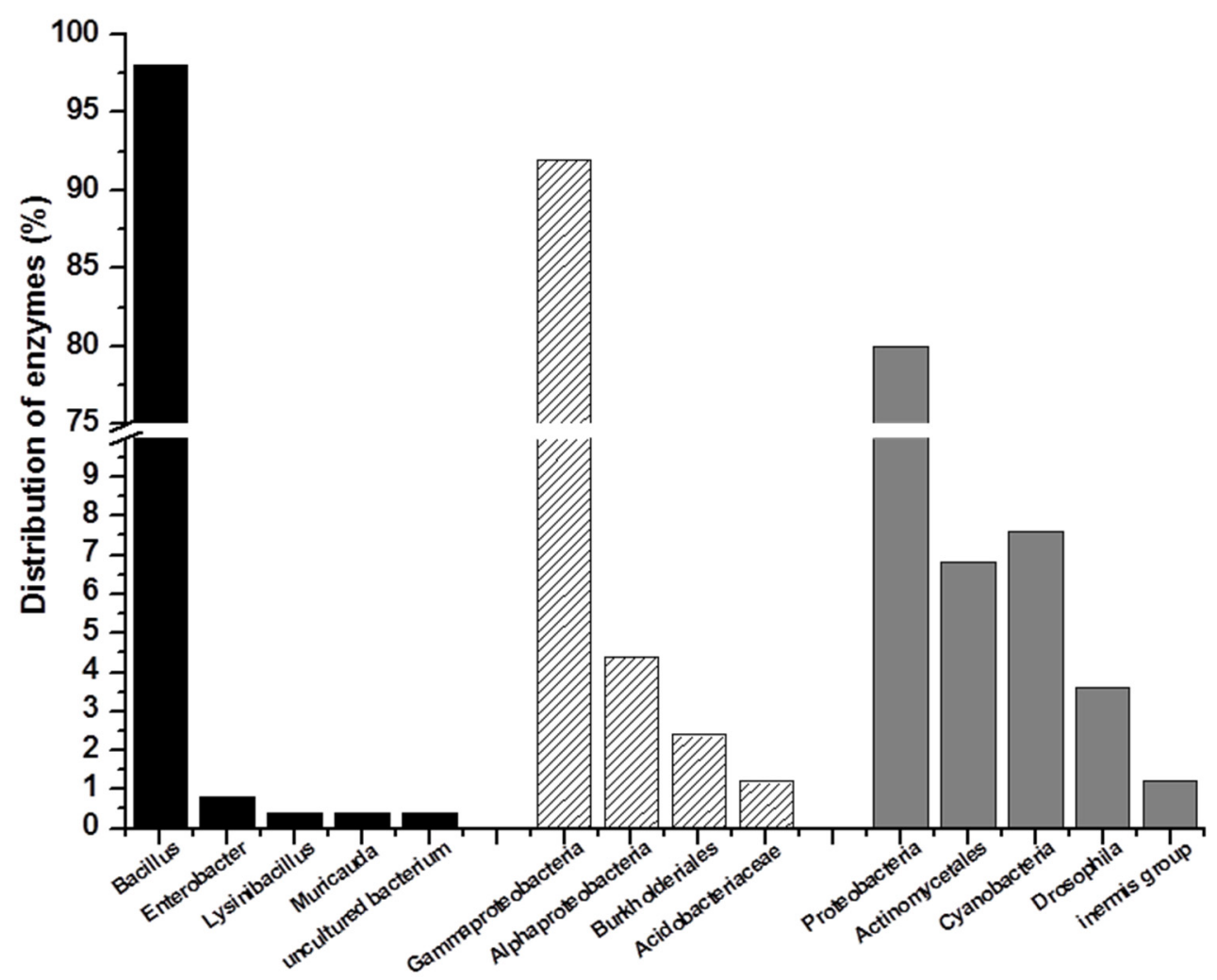

Figure 2. Distribution of AHL lactonase (left), amylase (middle) and alginate lyase (right). Calculation method of the percentage: The reported enzymes were bioinformatic analyzed and classified based on different species source.

\subsection{Marine Resources of AHL Lactonase and Research Methods}

Only a few types of AHL lactonases have been discovered from marine environments. QsdH, which was discovered from marine Pseudoalteromonas, is not a single protein but combines with a special transporter of small molecules that belongs to the resistance-nodulation-cell division (RND) superfamily [30]. It is promising to exploit the quorum-quenching enzymes from relatively unknown marine environments. Several new methods have been studied for quorum quenching enzymes exploration. Recently, our group developed a novel high-throughput strategy for identifying bacterial strains with quorum-quenching activity [31]. This method (A136 liquid X-gal (5-bromo-4-chloro-3-indolyl- $\beta$-D-galactopyranoside) assay) is based on the measurement of residual AHL molecules after the reaction (Figure 3). Compared with previous strategies, the main improvement of the A136 liquid X-gal assay involves the detection of $\beta$-galactosidase activity in a rapid and quantitative manner. Although the ONPG assay (2-nitrophenyl $\beta$-D-galactopyranoside) is a broadly approved strategy to measure $\beta$-galactosidase activity, the complex process of the ONPG assay causes low throughput and relatively poor efficiency [31]. However, the A136 liquid X-gal assay can be performed in a 96-well plate layout with one-step detection of enzymatic activity in a high-throughput manner. With the A136 liquid X-gal assay, 25 quorum-quenching bacterial strains belonging to different species were identified from hundreds of candidate marine bacterial strains. Additionally, with this method, several genera with quorum quenching activity, such as Flaviramulus, Muricauda and Rhodobacter, were identified [31]. 


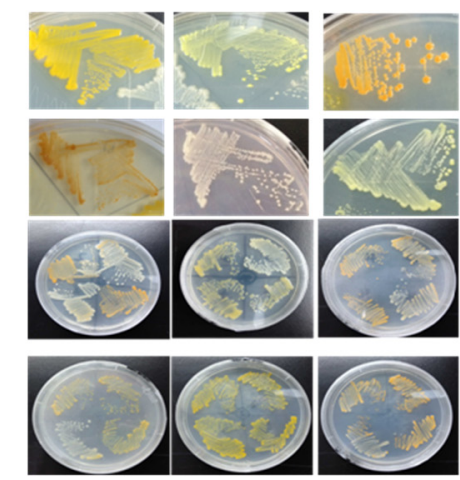

Bacterial resource isolation

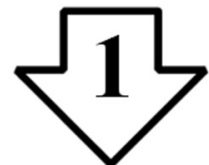

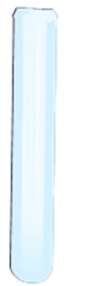
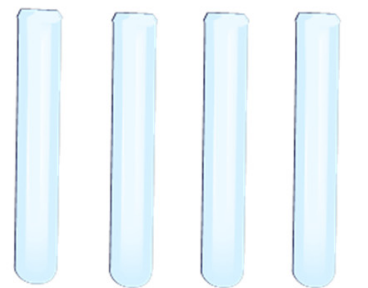

Bacterial culture with exogenous AHL signal molecular

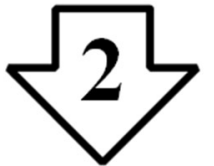

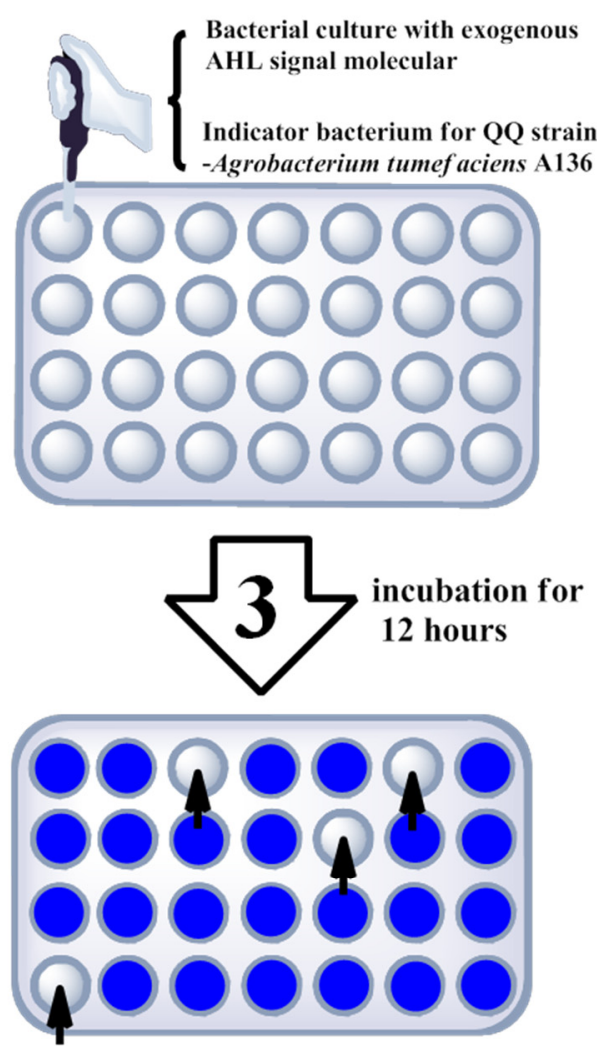

Four strains with $Q Q$ (quorum quenching) activity

Figure 3. Schematic diagram of high-throughput method for identifying quorum quenching bacteria.

The Gram-negative strain Muricauda olearia Th120, which was isolated from Paralichthys olivaceus, exhibits high-level quorum-quenching activity. Sequencing and bioinformatic results demonstrate that the genome contains a gene encoding AHL lactonase named MomL. MomL consists of 294 amino acids with a molecular weight of approximately 38.4 KDa [29]. MomL belongs to the metallo- $\beta$-lactamase family, and the homolog exhibits a $24.5 \%$ similarity with AiiA. In addition to containing the conserved ion-binding site HXDH-H-D, MomL possesses two additional novel characteristic features: (1) the protein possesses one special signal peptide consisting of 21 amino acids at the $N$-terminus of the sequence that presumably facilitate the protein secretory ability; (2) The highest amino acid identity compared with other terrestrial homologs is only approximately $20 \%$. Using the pTWIN1 vector, MomL protein was heterologously-expressed and purified, and the expected approximately $30 \mathrm{KDa}$ band was observed in SDS-PAGE (SDS-polyacrylamide gel electrophoresis). LC-MS (liquid chromatography-mass spectrometry) results demonstrated that MomL degrades C6 or C12-HSL to linear products by hydrolyzing lactonic rings. In vitro enzyme assays indicated that MomL possesses high activity and broad substrate selectivity. Kinetic results indicated MomL had 10-fold increased C6-HSL (C6-homoserine lactones) degrading activity compared with AiiA protein [29].

Moreover, using several developed and promising technologies, we performed the following assays using MomL. First, we performed directed evolution of MomL (Figure 4). Although this strategy is not broadly used to engineer marine microbial enzymes, the strategy has been widely used in terrestrial microorganisms. Using directed evolution, Yi Tang's group at the University of California Los Angeles enhanced the activity of LovD up to 11-fold, which is an acyltransferase that converts the 
inactive secondary metabolite monacolin J acid into the cholesterol-lowering lovastatin [32]. Regarding the directed mutation strategy, the first step involves constructing a random mutation gene pool of the target protein. To maintain the activity of the mutated protein, the mutation rate was controlled by adjusting the error-prone PCR and sequential error-prone PCR protocols. A mutation rate of 1 to 3 mutated points in every 100 amino acids was suitable for an ideal gene pool [32]. Several screening strategies could be used for positive mutation selection of different proteins with improved activity. These strategies can be easily used for MomL engineering when combined with the high-throughput selection method described above.

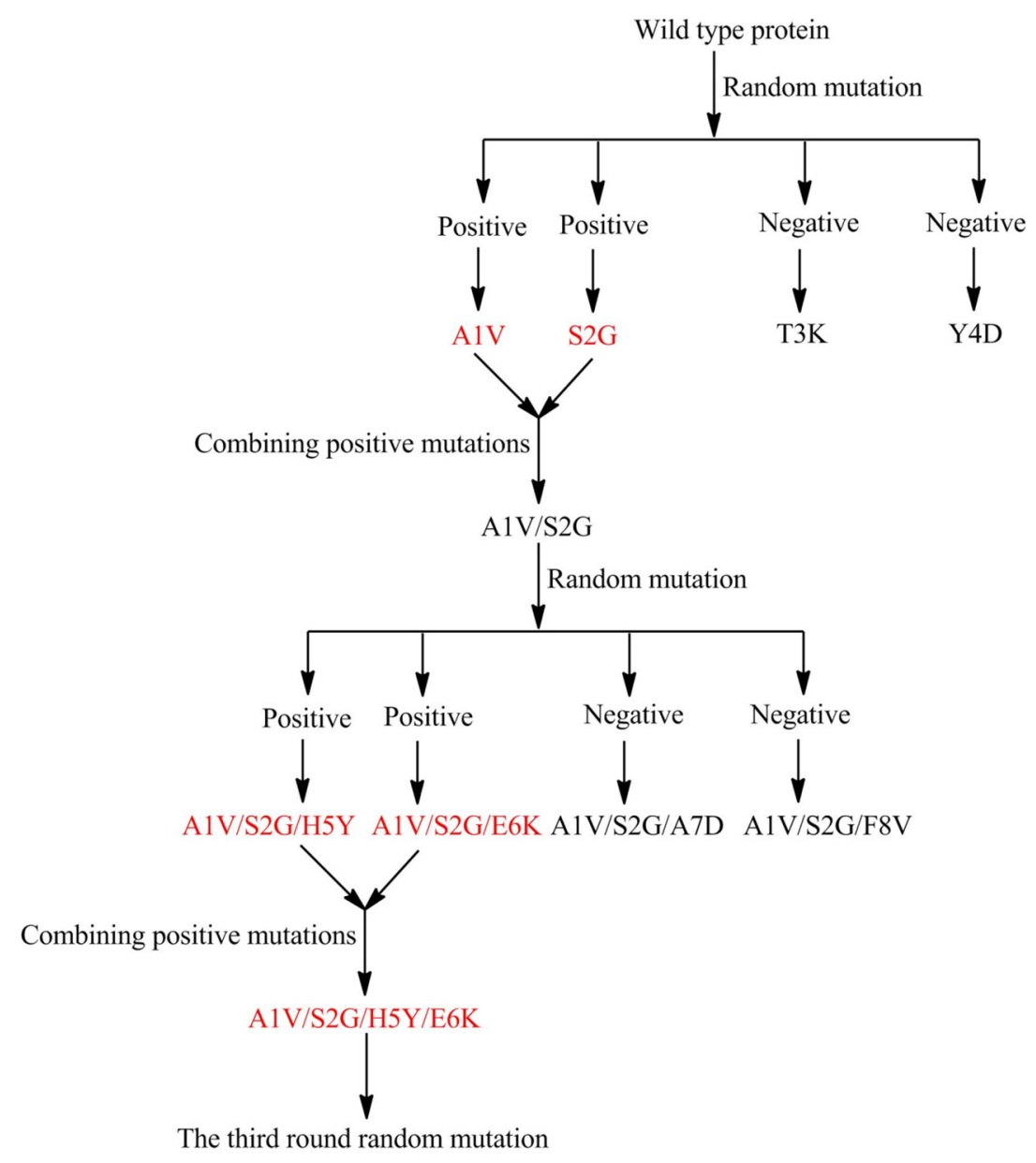

Figure 4. Schematic diagram of directed evolution assay. (A1V means alanine was replaced by valine).

Another novel research area for marine microbial enzymes involves gene regulation and signaling cascade pathways. Regulatory studies may aid in the exploration of silencing functional genes and identifying positive regulatory elements of target genes. After identifying positive regulatory genes, another important strategy involves synthetic biology. Through the construction of vectors overexpressing positive regulatory genes, the transcriptional level of the target gene is upregulated, and enzymatic expression is increased. The study of synthetic biology and related research in marine microorganisms is also a relatively new area compared with terrestrial microorganisms. Instead of reviewing marine bacteria, we use soil bacteria as references. Lysobacter, a genus of Gram-negative gliding bacteria, has emerged as a novel group of biocontrol agents [33]. Additionally, these species are a new bacterial source of bioactive natural products [34,35]. Liangcheng Du's laboratory at the University of Nebraska-Lincoln developed a simple method to identify target transformants based on yellow to black color change as a selection marker [36]. Using this special overexpression vector, these researchers constructed various vectors that overexpressed a positive regulator gene identified 
in the WAP-8294A biosynthetic gene cluster that acted as a potent anti-MRSA (Methicillin-resistant Staphylococcus aureus) antibiotic [37], and another regulator gene from the HSAF (Heat Stable Antifungal Factor) biosynthetic gene cluster that acted as an antifungal compound with a novel mode of action $[38,39]$. The enzymes that produced both WAP-8294A2 and HSAF were upregulated in the strain with overexpressed TonB-dependent receptor, and the production of WAP-8294A and HSAF increased by 2 -fold and 7 -fold, respectively, compared with the wild type. This work represents a successful metabolic engineering technique in a terrestrial microorganism that can also be used to manipulate unexplored marine bacteria enzyme sources.

Signal molecules regulate the transcriptional level of multiple genes, which serves as an additional strategy for exploring functional genes, especially for discovery of silenced gene clusters. This strategy is also relatively newly developed for marine microorganisms compared with soil studies. Recently, with Lysobacter, researchers identified a small molecule metabolite (LeDSF3) that regulates the biosynthesis of HSAF [40]. The addition of LeDSF3 in L. enzymogenes cultures increases HSAF biosynthetic gene transcription and HSAF yield. Additionally, the researchers identified the signaling cascade pathway. LeDSF3-regulated HSAF transcription and production are dependent on the two-component regulatory system, RpfC/RpfG (histidine kinase sensor/response regulator). Moreover, the global regulator cAMP receptor-like protein, which is a product of the clp gene, is another essential element in this signaling cascade pathway [40]. In addition to LeDSF3, AHL, indole, diffusible signal factor (DSF), yellow pigments and several other small molecules regulate the transcription of enzyme-encoding genes (Figure 5) [41-46]. We have used these strategies to identify the signal cascade of MomL, and the experiment is ongoing with promising progress.

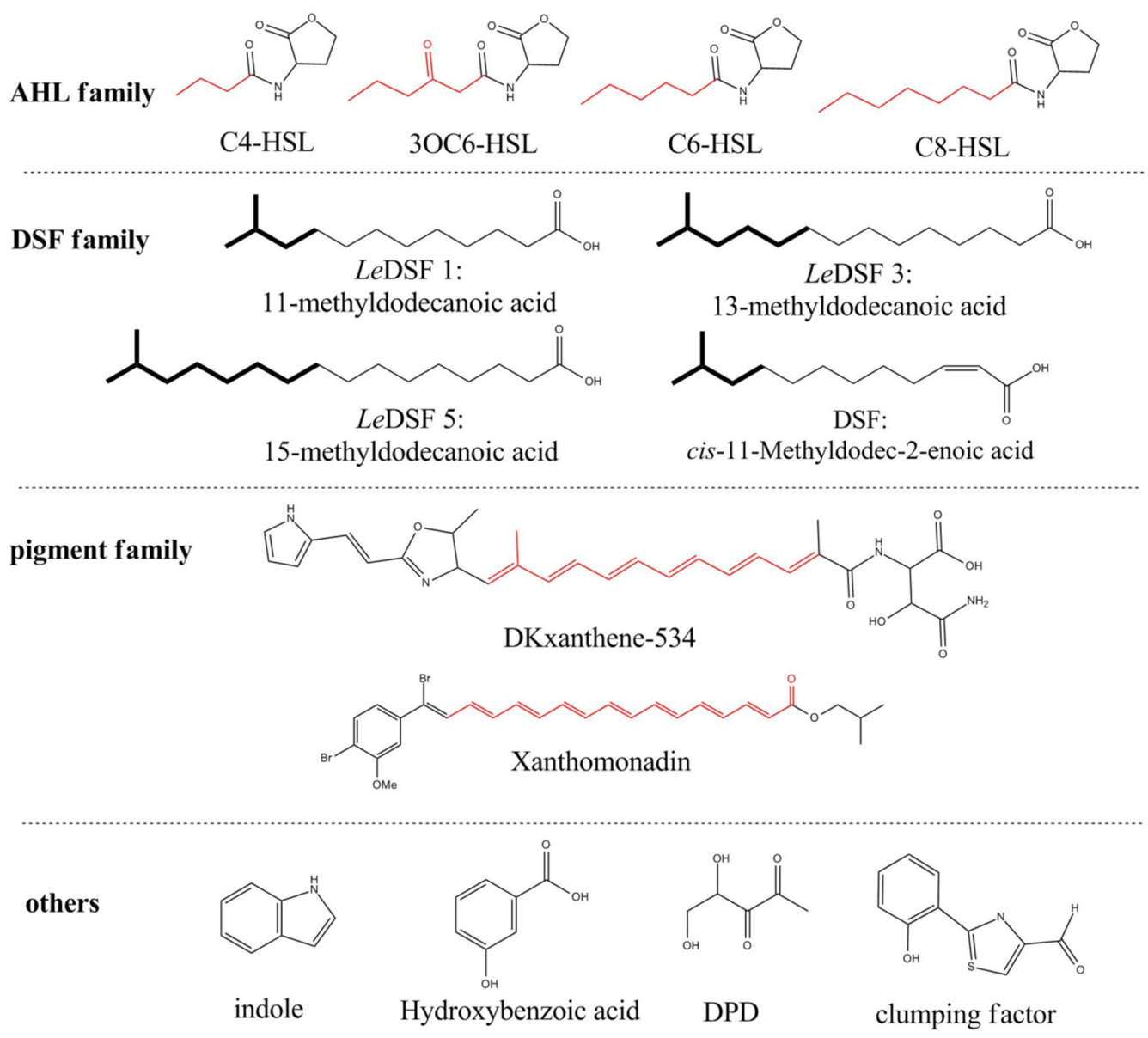

Figure 5. The list of well-known signal molecules. 


\subsection{Prospects for AHL Lactonase}

Quorum quenching strategy is attracting increased attentions. AHL lactonase, as one kind of quorum quenching enzyme, can be applied in a range of industries. For instance, it can be used in biological control and aquaculture fields to inhibit the toxicities of pathogenic bacterium. It can be used as antistaling agents of fruits and vegetables during long-distance transport. Also, this novel quorum quenching enzyme will be widely applied in antifouling fields to inhibit the formation of bacterial biofilm. Marine-derived AHL lactonase is under highly undeveloped state. Through the updated techniques and methods mentioned above, it is believed that more enzyme resources will be exploited for various applications.

\section{Amylase}

\subsection{Introduction}

Starch, an important component of the human diet, is one of the main energy storage forms of commercial crops, such as wheat, rice, corn, potatoes and cassava. Based on structure, starches are categorized as amylose and amylopectin. Amylose is linked by a $\alpha-1,4$ glucosidic bond, whereas amylopectin is linked by a $\alpha-1,6$ branch bond as well as a $\alpha-1,4$ linked bond [47]. Currently, acid-catalyzed hydrolysis and enzyme-catalyzed hydrolysis are the main methods of amylo-degradation. Compared with acid-catalyzed hydrolysis, enzyme-catalyzed hydrolysis exhibits considerable advantages, such as substrate specificity and low-energy consumption. Here we listed the properties of well-studied and representative alpha-amylases (Table 2). 
Table 2. Properties of well-studied alpha-amylases.

\begin{tabular}{|c|c|c|c|c|c|c|c|c|c|}
\hline Stain & UniProtKB & $\begin{array}{l}\text { Molecular } \\
\text { Mass (kDa) }\end{array}$ & $\begin{array}{c}\text { Signal } \\
\text { Peptide (aa) }\end{array}$ & $\begin{array}{c}\text { Temperature } \\
\text { Optimum }\left({ }^{\circ} \mathrm{C}\right)\end{array}$ & Thermostabiliy & pH Optimum & pH Stability & $\begin{array}{l}\text { Specific Activity with } \\
\text { Soluble Starch (U/mg) }\end{array}$ & Reference \\
\hline Luteimonas abyssi & NM & 49 & 35 & 50 & $\begin{array}{l}34 \%, 50^{\circ} \mathrm{C} \\
20 \mathrm{~min}\end{array}$ & 9 & $\begin{array}{l}>50 \%, 6-11, \\
50^{\circ} \mathrm{C}, 1 \mathrm{~h}\end{array}$ & $8881^{\mathrm{a}}$ & [48] \\
\hline Bacillus licheniformis & Q208A7 & 55 & 29 & 90 & $\begin{array}{c}\text { Clear halos, } \\
100^{\circ} \mathrm{C}, 120 \mathrm{~min}\end{array}$ & NM & NM & NM & [49] \\
\hline $\begin{array}{c}\text { Bacillus } \\
\text { amyloliquefaciens }\end{array}$ & P00692 & 54.8 & 31 & 60 & NM & NM & NM & NM & [50] \\
\hline $\begin{array}{l}\text { Alteromonas haloplanctis } \\
\text { A23 }\end{array}$ & P29957 & 50 & 24 & 25 & $6 \%, 25^{\circ} \mathrm{C}$ & 7 & NM & NM & [51] \\
\hline $\begin{array}{c}\text { Bacillus sp. strain } \\
\text { KSM-K38 }\end{array}$ & Q93I48 & 55 & 21 & $55-60$ & $\begin{array}{l}20 \%, 50{ }^{\circ} \mathrm{C} \\
30 \mathrm{~min}\end{array}$ & $8.0-9.5$ & $\begin{array}{c}>80 \%, 6-11 \\
40^{\circ} \mathrm{C}, 30 \mathrm{~min}\end{array}$ & $4221^{a}$ & [52] \\
\hline $\begin{array}{l}\text { alkaliphilic bacterium } \\
\text { N10 }\end{array}$ & Q6WUB6 & 61 & 31 & 50 & $\begin{array}{l}71 \%, 50{ }^{\circ} \mathrm{C} \\
30 \mathrm{~min}\end{array}$ & 9.5 & $\begin{array}{l}>80 \%, 8.5-11 \\
50{ }^{\circ} \mathrm{C}, 10 \mathrm{~min}\end{array}$ & $7826^{a}$ & [53] \\
\hline Bacillus sp. XAL601 & Q45643 & 225 & 31 & 70 & NM & 9.0 & NM & $57.3^{\mathrm{a}}$ & {$[54]$} \\
\hline Bacillus sp. & O82839 & 53 & 31 & 55 & $\begin{array}{l}25 \%, 80^{\circ} \mathrm{C} \\
10 \mathrm{~min}\end{array}$ & $8.0-8.5$ & $\begin{array}{c}>50 \%, 6-9 \\
40{ }^{\circ} \mathrm{C}, 30 \mathrm{~min}\end{array}$ & $5009^{a}$ & [55] \\
\hline Nocardiopsis sp. 7326 & NM & 55 & NM & 35 & $\begin{array}{l}18 \%, 55^{\circ} \mathrm{C} \\
30 \mathrm{~min}\end{array}$ & 8.0 & $\begin{array}{l}>60 \%, 7-9 \\
4{ }^{\circ} \mathrm{C}, 24 \mathrm{~h}\end{array}$ & $548^{\mathrm{a}}$ & [56] \\
\hline $\begin{array}{l}\text { Bacillus sp. strain } \\
\text { GM8901 }\end{array}$ & NM & 97 & NM & 60 & $\begin{array}{c}37 \%, 60^{\circ} \mathrm{C} \\
2 \mathrm{~h}(-\mathrm{Ca}) \\
78 \%, 60^{\circ} \mathrm{C} \\
2 \mathrm{~h}(+\mathrm{Ca})\end{array}$ & $11-12$ & $\begin{array}{l}>85 \%, 6-13 \\
50^{\circ} \mathrm{C}, 1 \mathrm{~h}\end{array}$ & $157.5^{\mathrm{a}}$ & [57] \\
\hline $\begin{array}{c}\text { Bacillus sp. NRRL } \\
\text { B-3881 }\end{array}$ & NM & NM & NM & 50 & $50 \%, 55^{\circ} \mathrm{C}$ & 9.2 & $>50 \%, 7.0-10.5$ & $3485^{a}$ & [58] \\
\hline Bacillus acidicola & J9PQD2 & 62 & no signal & 60 & $\begin{array}{c}50 \%, 90{ }^{\circ} \mathrm{C} \\
10 \mathrm{~min}\end{array}$ & 4 & $\begin{array}{c}100 \%, 4,12 \mathrm{~h}, \\
100 \%, 3,1 \mathrm{~h}\end{array}$ & $1166^{\mathrm{a}}$ & [59] \\
\hline Lipomyces kononenkoae & Q01117 & 76 & 28 & 70 & $0,70^{\circ} \mathrm{C}, 10 \mathrm{~min}$ & $4.5-5.0$ & $>70 \%, 3-8,1 \mathrm{~h}$ & $258^{a}$ & [60] \\
\hline $\begin{array}{c}\text { Alicyclobacillus } \\
\text { acidocaldarius }\end{array}$ & C8WUR2 & 160 & 23 & 75 & NM & 3 & NM & $16.9^{\mathrm{b}}$ & [61] \\
\hline Bacillus sp. Ferdowsicous & P86331 & 53 & NM & 70 & $\begin{array}{c}75 \%, 75^{\circ} \mathrm{C} \\
45 \mathrm{~min}\end{array}$ & 4.5 & $\begin{array}{c}>75 \%, 3.5-6 \\
60 \mathrm{~min}\end{array}$ & $267^{\mathrm{a}}$ & [62] \\
\hline Bacillus acidocaldarius & NM & 68 & NM & 75 & $50 \%, 60^{\circ} \mathrm{C}, 5$ days & 3.5 & Stable below 4.5 & $257^{\mathrm{b}}$ & [63] \\
\hline Aspergillus penicillioides & NM & 42 & NM & 80 & $60 \%, 100^{\circ} \mathrm{C}$ & 9 & $>80 \%, 7-10$ & $118.42^{\mathrm{a}}$ & [64] \\
\hline $\begin{array}{l}\text { Talaromyces pinophilus } \\
1-95\end{array}$ & NM & 58 & NM & 55 & $<45^{\circ} \mathrm{C}, 1 \mathrm{~h}$ & $4-5$ & $5-9.5,24 \mathrm{~h}$ & $673.08^{a}$ & [65] \\
\hline Thermococcus sp. HJ21 & B4X9V8 & 51.4 & NM & 95 & $\begin{array}{c}50 \%, 90{ }^{\circ} \mathrm{C}, 5 \mathrm{~h}, \\
40 \%, 30 \% ; 100{ }^{\circ} \mathrm{C} ; \\
2 \mathrm{~h}, 3 \mathrm{~h}\end{array}$ & 5 & $5-9$ & $8.3^{\mathrm{a}}$ & [66] \\
\hline Malbranchea cinnamomea & K9L8F3 & 60.3 & 21 & 65 & $\begin{array}{c}50 \%, 60{ }^{\circ} \mathrm{C} \\
41.1 \mathrm{~min} \\
\end{array}$ & 6.5 & $\begin{array}{l}>90 \%, 5-10 \\
\quad 30 \mathrm{~min}\end{array}$ & $514.6^{\mathrm{a}}$ & [67] \\
\hline
\end{tabular}


Table 2. Cont

\begin{tabular}{|c|c|c|c|c|c|c|c|c|c|}
\hline Stain & UniProtKB & $\begin{array}{l}\text { Molecular } \\
\text { Mass (kDa) }\end{array}$ & $\begin{array}{c}\text { Signal } \\
\text { Peptide (aa) }\end{array}$ & $\begin{array}{c}\text { Temperature } \\
\text { Optimum }\left({ }^{\circ} \mathrm{C}\right)\end{array}$ & Thermostabiliy & pH Optimum & pH Stability & $\begin{array}{l}\text { Specific Activity with } \\
\text { Soluble Starch (U/mg) }\end{array}$ & Reference \\
\hline Aspergillus niveus & NM & 60 & NM & 65 & $50 \%, 70{ }^{\circ} \mathrm{C}, 20 \mathrm{~m}$ & 6 & $4-7,24 \mathrm{~h}$ & $168^{\mathrm{a}}$ & [68] \\
\hline $\begin{array}{c}\text { Thermoactinomyces } \\
\text { vulgaris }\end{array}$ & G8ZE61 & 40.6 & NM & 50 & $50 \%, 50^{\circ} \mathrm{C}, 2 \mathrm{~h}$ & $6-7$ & $4-9$ & $127,100.33^{b}$ & [69] \\
\hline Bacillus sp. AAH-31 & S6BGD1 & 91 & 28 & 70 & $<60^{\circ} \mathrm{C}$ & 8.5 & $6.4-10.3$ & $16.7^{\mathrm{a}}$ & [70] \\
\hline Paecilomyces variotii & NM & 75 & NM & 60 & $\begin{array}{l}50 \%, 60^{\circ} \mathrm{C}, \\
53 \mathrm{~min}\end{array}$ & 4 & $>70 \%, 5-8,1 \mathrm{~h}$ & $612.5^{\mathrm{a}}$ & [71] \\
\hline $\begin{array}{c}\text { Pseudoalteromonas } \\
\text { arctica GS230 }\end{array}$ & NM & 55 & 24 & 30 & $\begin{array}{l}49 \%, 30{ }^{\circ} \mathrm{C} \\
150 \mathrm{~min}\end{array}$ & 7.5 & $>60 \%, 7-8.5,1 \mathrm{~h}$ & $25.5^{\mathrm{a}}$ & [72] \\
\hline Bacillus sp. YX-1 & A9YDD9 & 56 & 31 & $40-50$ & $60 \%, 60^{\circ} \mathrm{C}, 1 \mathrm{~h}$ & 5 & $\begin{array}{l}>80 \%, 4.5-11 \\
1 \mathrm{~h}\end{array}$ & $607^{b}$ & [73] \\
\hline $\begin{array}{c}\text { Geobacillus } \\
\text { thermoleovorans }\end{array}$ & NM & 26 & NM & 100 & $50 \%, 100^{\circ} \mathrm{C}, 3.6 \mathrm{~h}$ & 8 & $\begin{array}{l}50 \%, 6,4.5 \mathrm{~h}, \\
50 \%, 7,7.5 \mathrm{~h}\end{array}$ & $450^{\mathrm{a}}$ & [74] \\
\hline $\begin{array}{c}\text { Fusicoccum sp. } \\
\text { BCC } 4124\end{array}$ & Q0Z8K1 & 50 & no signal & 70 & $95 \%, 50{ }^{\circ} \mathrm{C}, 1 \mathrm{~h}$ & 7 & NM & $90^{\mathrm{a}}$ & [75] \\
\hline Bacillus subtilis KCC103 & A8VWC5 & 53 & 33 & $65-70$ & $50 \%, 70^{\circ} \mathrm{C}, 7 \mathrm{~min}$ & $6-7$ & $>98 \%, 5-9.5$ & $483^{\mathrm{a}}$ & [76] \\
\hline Bacillus subtilis AX20 & NM & 149 & NM & 55 & $50^{\circ} \mathrm{C}, 30 \mathrm{~min}$ & 6 & $5-9,24 \mathrm{~h}$ & $4133^{a}$ & [77] \\
\hline Halothermothrix orenii & Q8GPL8 & 60 & 23 & 65 & $37-75^{\circ} \mathrm{C}$ & 7.5 & $6-9.5$ & $22.32^{\mathrm{a}}$ & [78] \\
\hline $\begin{array}{c}\text { Bacillus } \\
\text { stearothermophilus }\end{array}$ & NM & 64 & NM & 50 & $92 \%, 100{ }^{\circ} \mathrm{C}, 1 \mathrm{~h}$ & 7 & $\begin{array}{l}23 \%, 3,1 \mathrm{~h} \\
26 \%, 10,1 \mathrm{~h}\end{array}$ & $77.2^{b}$ & [79] \\
\hline $\begin{array}{l}\text { Thermus filiformis Ork } \\
\text { A2 }\end{array}$ & NM & 60 & NM & 95 & $\begin{array}{c}50 \%, 95^{\circ} \mathrm{C} \\
19 \min \end{array}$ & $5.5-6$ & $>80 \%, 4.5-8,1 \mathrm{~h}$ & $6352^{\mathrm{b}}$ & [80] \\
\hline Bacillus subtilis & NM & 48 & NM & 50 & $70 \%, 60^{\circ} \mathrm{C}, 1 \mathrm{~h}$ & 6.5 & $5-6.5$ & $772.7^{\mathrm{a}}$ & [81] \\
\hline $\begin{array}{l}\text { Clostridium perfringens } \\
\text { NCTC } 8679\end{array}$ & NM & 76 & NM & 30 & NM & 6.5 & NM & NM & [82] \\
\hline $\begin{array}{l}\text { Escherichia coli (strain } \\
\mathrm{K} 12)\end{array}$ & P25718 & 75.7 & 17 & NM & NM & 8 & NM & NM & [83] \\
\hline Bacillus subtilis & P00691 & 67 & 27 & NM & NM & 8.5 & NM & NM & {$[84]$} \\
\hline
\end{tabular}

${ }^{a}$ Enzyme activity are measured by DNS method; ${ }^{\mathrm{b}}$ Enzyme activity are measured by the colored starch- $\mathrm{I}_{2}$ complex method; NM means not mention in the essays. 


\subsection{Marine Resources of Amylase and Related Catalytic Mechanisms}

Currently, heat-stable $\alpha$-amylases have been well studied and applied in a series of industrial fields. As the development of industry, the demand for cold-active amylase is attracting increasingly attention. Different from terrestrial resources of amylase, many of the marine resources of amylase has high activity in low temperature as over $75 \%$ of the ocean is in $0-6{ }^{\circ} \mathrm{C}$. Therefore, the marine environment is an ideal area to find cold-active amylase. In Table 2, we can clearly find that the optimum temperature of $\alpha$-amylase from Alteromonas haloplanctis A23, isolated from Antarctica, is $25^{\circ} \mathrm{C}$ and it has high activity in low temperature. In deep sea sediment of Prydz Bay, Antarctic, a cold-adapted $\alpha$-amylase from Nocardiopsis sp. 7326 was identified. It can retain $38 \%$ of its highest activity at $0{ }^{\circ} \mathrm{C}$. Recently, our group found a novel alkalophilic $\alpha$-amylase LaaA which has the highest specific activity reported. The specific activity reached highly to $8881 \mathrm{U} / \mathrm{mg}$. it was cloned from deep-sea bacterium Luteimonas abyssi XH031 ${ }^{\mathrm{T}}$ which isolated from the sediment of the South Pacific Gyre with low temperature. It even maintained $38 \%$ residual activity at $10{ }^{\circ} \mathrm{C}$ [48].

Given the convenience of genetic and molecular biological manipulation, prokaryotes are the most important resource for $\alpha$-amylase exploration (Figure 2). Previous studies demonstrated that $\alpha$-amylase consists of three domains: A, B and C [85]. Domain A, which includes active site residues and is directly related to catalytic reaction, forms the core portion of $\alpha$-amylase. Domains $B$ and $C$ are related to substrate specificity and active site stability [86]. Thermostability is one of the most valuable characteristic features of amylase. Studies have demonstrated that protein thermostability is mainly influenced by hydrogen bonding, hydrophobic interaction, electrostatic interactions and packing [87]. Through studies of $\alpha$-amylases from Bacillus, two stages of thermo-inactivation have been revealed: the partial unfolded state, which is a reversible step, and the fully unfolded state, which is an irreversible step. With increasing temperatures, the enzyme reaches the partial unfolded state first. When the temperature reaches a certain level, the enzyme is fully unfolded and totally inactive [88]. It is hypothesized that the irreversible inactivation is due to covalent modifications of polypeptide chains or that a higher energy barrier is required during the folding process [86].

To date, most of the well-studied $\alpha$-amylases contain a conserved calcium site, which is potentially related to enzyme stability and activity [89]. The conserved calcium site is located far away from the active site; thus, this site does not participate in the catalytic reaction but plays an important structural role in enzyme stability and activity [86]. The conserved calcium ion interacts with four amino acid residues, and three of them are strictly conserved in both structure and sequence [90]. Asn104, Asp200 and His235 are three conserved sites in Bacillus licheniformis $\alpha$-amylase (BLA) [91]. Mischa et al. [90] first equivocally elucidated the mechanism of calcium-activating $\alpha$-amylase, and this group identified a large region that contains 21 disordered residues. The disordered to ordered transition that occurs in this region is mediated by calcium, which leads to the formation of one wall of the cleft containing the extended substrate binding site [90]. If this region is disrupted by two extra residues (Glu-Gly), the conformation of calcium binding is also modified, and thermal stability is subsequently decreased [92].

Great efforts have been made during recent decades through site-directed mutagenesis and directed evolution to improve the properties of promising $\alpha$-amylases, such as catalytic activity, oxidation resistance, $\mathrm{pH}$ tolerance, and temperature tolerance. Directed evolution mainly applies to the enzymes with biochemical and structural properties that remain poorly understood. Site-directed mutagenesis is based on thorough research of enzymatic properties. Using homologous sequence alignment or information regarding tertiary structure, enzymes can be purposefully modified. For example, to improve the thermal stability of $\alpha$-amylase from Bacillus megaterium WHO (BMW), researchers compared BMW-amylase with the most similar protein (Halothermothrix orenii $\alpha$-amylase, $67 \%$ ) through bioinformatic methods and modified the protein using site-specific mutagenesis. The thermal stability was dramatically improved by H58I mutation, which corresponds to Ile50 in H. orenii $\alpha$-amylase [93].

The deletion of residues is an effective method to improve thermostability. Studies demonstrated that BLA and BAA (Bacillus amyloliquefaciens $\alpha$-amylase) are highly similar in structure, but a significant 
difference in thermostability was noted. The sequence alignment of BAA and BLA demonstrated the absence of two amino acids, 209E and 210G, in BLA compared with BAA. Then, the mutant strain BAA- $\triangle \mathrm{EG}$ (209E and 210G were mutated) was constructed. The results demonstrated that the maximal thermostability was increased by ten degrees compared with the wild type BAA [92]. Similar studies by Mamdouh et al. [94] reported that the amylase of Bacillus stearothermophilus US100 has an additional loop compared with the model of BLA. The deletion of two residues (Ile214 and Gly215) increased thermostability and reduced calcium requirements. Further studies revealed that the stability of the loop affects the thermostability. The additional loop (containing residues Gly213, Ile214 and Gly215) along with the neighboring residues Arg212 and Lys216 play a critical role in stabilizing the structure of $\alpha$-amylase and the calcium-binding site of calcium I. The structure was stabilized via the interaction between Lys216 and Phe194 and Asp238. Moreover, the stability of Lys216 is directly related to the stability of the GIG loop [95]. Hydrogen bonding and salt bridges have the important function of maintaining the stability of $\alpha$-amylase at low $\mathrm{pH}$ [96-98]. The stability of mutants at low pH was particularly increased by H275D, H293D and H310D mutations. Histidine (His) is a basic amino acid with positive charges, whereas aspartic acid (Asp) is an acidic amino acid with negative charges. The survey demonstrates that Asp can stabilize the structure of $\alpha$-amylase by interacting with hydrogen bonding and salt bridges under acidic conditions [99]. Salt bridges are also related by the high thermal stability of BLA [97]. The lysine residues (Lys88, Lys253 and Lys385) interact with each other to form a stable salt bridge [97]. It is proposed that the interaction between two residues with similar charges enhances protein stability. Karimeh et al. [100] found that P407H mutations improved the thermal stability of BAA. Regarding mutated BAA, His407 is located in calcium III, which forms a His-His pair with the neighboring amino acid His406.

\subsection{Prospects for Amylase}

$\alpha$-amylase is widely applied in food, fermentation and detergent industries. Furthermore, in the medical field, $\alpha$-amylase can be used as drug targets for treating diabetes, obesity and high cholesterol, etc. As the increasing demand of different special properties of $\alpha$-amylase in the industry and research fields, the complex marine environments provide the possibility of finding various of $\alpha$-amylases. The study of marine resources of amylase is becoming increasingly popular. Besides, protein engineering is an efficient method to improve the properties of $\alpha$-amylase and plays an increasingly important role in the research of $\alpha$-amylase.

\section{Alginate Lyase}

\subsection{Introduction}

Algin is a linear complex copolymer composed of mannuronate acid $(\mathrm{M})$ and guluronic acid $(\mathrm{G})$ that was originally extracted from the mesenchyme of kelp, gulfweed, and seaweed (Figure 6). Alginate lyase degradation products include oligosaccharides, which exhibit various bioactivities, such as antibiosis, anti-cancer, anti-tumor and promoting plant growth. Theses characteristic features allow these proteins to have broad application prospects in medical and agricultural fields. The methods of algin degradation include acid hydrolysis, chemical oxidation and enzymolysis, among which enzymolysis has great potential usage given its high specificity and reaction efficiency.

Alginate lyase is a type of enzyme that specifically degrades algin and is primarily found in microorganisms, animals and plants. Most bacterial alginate lyases are from Gamma-proteobacteria (Figure 2). Alginate lyases derived from microorganisms are more stable and exhibit increased activity compared with those obtained from plants and animals. Various types of classification have been reported, including those based on the specificity of the degradation substrate. In addition, algin enzymes can be classified as a mannuronate acid lyase, which exclusively degrades the $M$ section, or a guluronic acid lyase, which exclusively degrades the G section (Figure 6). At present, most of the 
well-studied alginate lyases exhibit $\mathrm{M}$ section-degrading activity, whereas a small proportion degrades both $\mathrm{M}$ and $\mathrm{G}$ sections (Figure 6) [101].

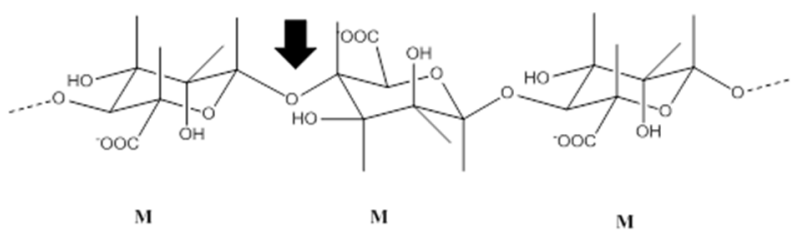

Poly-M fragment
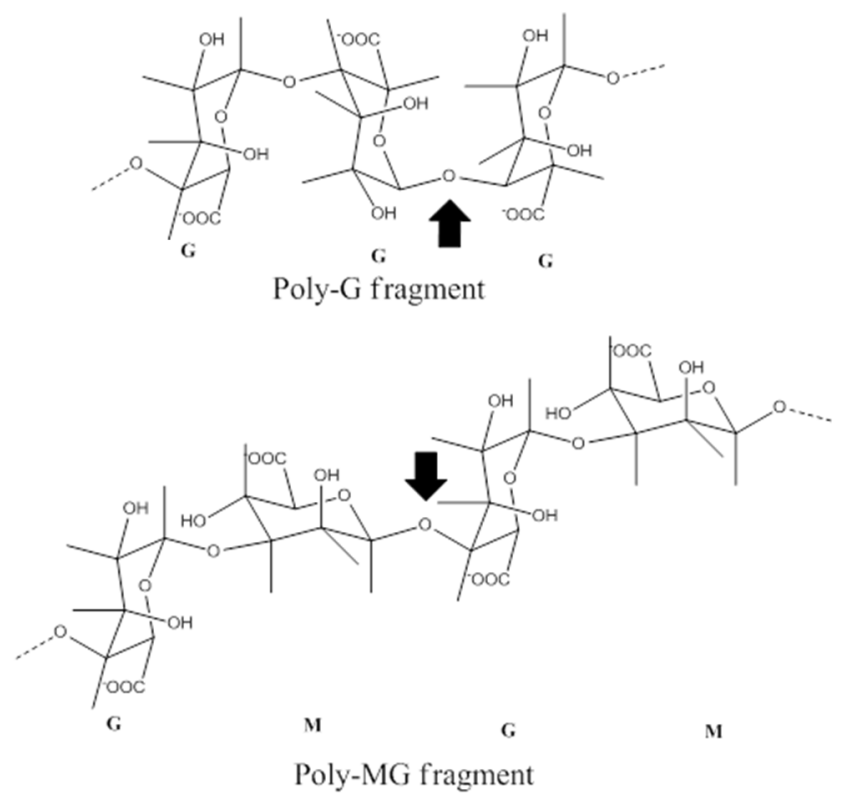

Figure 6. Structure of algin and the mode of action of alginate lyase.

\subsection{Marine Resources of Alginate Lyase and Catalytic Mechanisms}

Given the special environment and promising potential, marine alginate lyase studies have become common in the last several decades. Tseng and colleagues isolated two types of alginate lyases from Vibrio sp. AL-9 in 1992. One type breaks the $\alpha-1,4$ glycosidic bond of guluronic acid, whereas the other type breaks the $\beta-1,4$ glycosidic bond of mannuronate acid [102]. Moreover, this group also identified an alginate lyase that degrades guluronic acid in Vibrio sp. AL-128 [103]. The alginate lyase isolated from Vibrio sp. QY101 by Song et al. [104] exhibited obvious activity for both mannuronate acid and guluronic acid. For the first time, this group reported that the 9-amino acid region (YXRESLREM) appears not only in guluronic acid lyase but also in mannuronate acid lyase [105]. Takeshita et al. identified one novel alginate lyase from a Vibrio species isolated from the intestinal tract of red snapper [106]. The special alginate lyase retains $45 \%$ of catalytic activity under heat shock conditions of $100{ }^{\circ} \mathrm{C}$. Moreover, activity is also retained after treatment with $3 \%$ SDS in $25^{\circ} \mathrm{C}$ for $30 \mathrm{~min}$ [106].

In 2009, Liu et al. [107] constructed the recombinant plasmid pINA1317-Y1CWP110 with alginate lyase (AlyVI) isolated from Vibrio sp. QY101 as the target gene. This enzyme has considerable catalytic degradation activity if expressed in Yarrowia lipolytica. Moreover, this enzyme degrades mannuronate acid, guluronic acid, and alginate and produces a series of oligos with different lengths [107]. Alginate lyase was expressed in Saccharomycetes for the first time, and different oligosaccharide lengths were produced. In the bacterial strain Pseudoalteromonas atlantica AR06, some research groups used homologous recombination technology to fuse green fluorescent protein (GFP) to the C-terminus of alginate lyase AlyA, demonstrating that the bacterial strain has normal degradation activity and is able to release fluorescence. As a visible gene expression tool, GFP is convenient for biochemical 
and catalytic studies of alginate lyase. Recently, several additional alginate lyases have been well studied. Liu et al. [108] reported for the first time that the extracellular alginate lyase-like protein from Pseudomonas fluorescens exhibits high degradation activity for alginate. Dong and other scientists performed a study on bacteria isolated from the Arctic marine seaweed that produces alginate lyase [109]. In total, 65 bacterial strains were isolated from the kelp specimen, 21 of which exhibited alginate lyase activity. Among these isolates, 11 bacterial strains exhibited an optimum temperature between $20^{\circ} \mathrm{C}$ and $30{ }^{\circ} \mathrm{C}$, which indicates that the extracellular lyases are cryophilic enzymes [109]. Moreover, the bacterial strains Psychrobacter, Winogradskyella, Psychromonas and Polaribacter produce alginate lyase. We have recently focused our studies on Luteimonas abyssi sp. nov., which was isolated from the abyssal sediment under the circulating area of the South Pacific Ocean. Given that the strain lives in low-temperature environments and possesses alginate lyase activity, we hypothesize that alginate lyase is a cold-adaptive enzyme.

Previous studies identified different degradation products of alginate lyase under different $\mathrm{pH}$ conditions. For example, vAL-1 from PL-14 exhibits glucuronic acid degradation activity. In addition, this enzyme also degrades algin under alkaline conditions [110]. The purified alginate lyase Smlt1473 from $S$. maltophilia inducing exhibits hyaluronic acid degradation activity at a $\mathrm{pH}$ of 5 , guluronic acid degradation activity at a $\mathrm{pH}$ of 7 and alginate degradation activity at a $\mathrm{pH}$ of 9 [111].

Secondly, according to the similarity of amino acid sequence, alginate lyases may be classified into the PL-5, PL-7 and PL-15 families. In the PL-5 family [112], 41 alginate lyases have been identified to date, all of which are from microorganisms. In addition, 86 alginate lyases have been discovered in the PL-7 family, including 84 from bacteria and only 2 from eukaryotic cells. The PL-15 family currently has 11 alginate lyases, and all of them are from bacteria. Thus, most of the identified alginate lyases have been identified in bacteria.

Thirdly, alginate lyases can be divided into three categories based on molecular weight [113]: 20 to $35 \mathrm{kD}$, approximately $40 \mathrm{kD}$ and approximately $60 \mathrm{kD}$. The first type of enzyme (20 to $35 \mathrm{kD})$ exhibits a variety of substrate specificity. Given that the alginate lyases with a molecular weight of approximately $40 \mathrm{kD}$ have degradation activity specific to the M section [114] and most of them contain the common conserved sequence NNHSYW, it is inferred that this sequence is related to the $\mathrm{M}$ section-degradation activity. The homologous sequence YFKAGXYXQ of the C-terminus is another characteristic feature of small alginate lyases [101]. However, this same sequence was recently identified in AlyPI lyase, which is a member of the 60-kD family [115]. By comparing the homology of abalone alginate lyases (HdAly) with members of the PL-14 family, such as turban shell SP2 and chlorella virus CL2, Sayo Yamamoto et al. [116] reported that Arg92, Lys95, Arg110, Arg119, and Lys19 are particularly highly conservative amino acid residues. Utilizing site-specific mutagenesis technology, it was discovered that Lys95 mutations cause complete enzymatic inactivation, whereas Arg92, Arg110 and Arg119 mutations lead to reductions in activity greater than 65\%, thus suggesting that the Arg92 to Arg119 region is closely related to HdAly activity [116].

To date, all of the alginate degradation enzymes have been classified as lyases, and no hydrolytic enzymes have been reported [117]. Alginate lyases catalyze the degradation of alginate via a $\beta$-elimination mechanism by breaking $\alpha-1,4$ glycosidic bonds and yielding oligosaccharides with an unsaturated double bond at the non-reducing end. A portion of the reaction in which alginate lyase is cleaved can be induced by a specific substrate. For example, Matsushima et al. [118,119] reported that alyA gene transcription in Pseudoalteromonasatlantica AR06 is induced by alginate in basic medium.

\subsection{Prospects for Alginate Lyase}

Alginate lyases can be utilized in multiple industrial and medical areas. Alginate lyase can be used for developing new methods of tissue regeneration. For example, stem cell cultivation needs alginate hydrogel as a biological support. However, mammals cannot produce alginate lyase, and thus, alginate hydrogel cannot be easily degraded. Theoretically, alginate lyase provides a viable way to solve this problem [120]. Alginate lyase can also improve the drug susceptibility of biofilms, working 
as quorum sensing inhibitors [121]. Moreover, it has an inhibitory effect on the pathogens of pulmonary cystic fibrosis. Pediococcus sp. Ab1, which has alginate lyase activity, can be used as a probiotic to improve the intestinal microflora and nutritional status of abalone during their cultivation [122].

\section{Chitinase}

\subsection{Introduction}

Chitin is an $N$-acetyl-glucosamine homopolymer linked by a $\beta$-1,4-glucosidic bond [123] that is structurally identical to cellulose, except that the hydroxyl group in cellulose at $\mathrm{C} 2$ is replaced by an acetamide group [124]. Chitin is a particularly rich and important nutrient and energy source for maintaining the ecosystems of marine environments. The majority of chitin originates from marine ecosystems, and chitinolytic marine bacteria play a critical role in recycling chitinous materials, such as exoskeletons of crustaceans and insects. Moreover, chitinolytic marine bacteria are also important to maintain the balance of marine ecosystem. The biofunction of chitin mainly involves its degradation product oligochitosan, which is capable of resisting fungus, tumors, plant diseases, and related pests. Oligochitosan also alters the body's immunological function. Compared with traditional chemical approach, oligochitosan production by biological methods is milder and more environmentally friendly. Thus, chintinase studies have drawn increased attention during recent decades.

\subsection{Marine Resources of Chitinase and Catalytic Mechanisms}

Currently, chitinases have been identified in a series of marine organisms, such as Alteromonas sp. O7, V. parahaemolyticus [125], Salinivibrio costicola [126] and Microbulbifer degradans [127]. Chitinase is responsible for hydrolyzing the $\beta$-1,4-glycosidic bond of different types of chitin. Based on catalytic domain similarities, chitinase can be divided into two families: 18 and 19. Family 18 includes chitinases from bacteria, fungi, viruses, animals and some plants, whereas family 19 includes chitinases from most plants and special bacteria, such as chitinase C (ChiC) identified from Streptomyces griseus [128]. The chitinases of the two families, which potentially evolved from different ancestors, possess different catalytic mechanisms [129]. The catalytic domain of the GH18 family has a typical triosephosphate isomerase (TIM) structure that forms an inner barrel with $8 \alpha$-helixes surrounded by an outer barrel of $8 \beta$-sheets. Whereas the catalytic domain of the GH19 family has a high proportion of $\alpha$-helixes, and its structure is similar to chitosanase and lysozyme. GH18 contains 3 groups (ChiA/ChiB/ChiC), which are classified according to amino acid sequence differences in the catalytic domain. ChiA and ChiB hydrolyze chitin chains towards opposite direction, whereas ChiC is an endochitinase [130]. Most chitinases from marine microorganisms belong to family 18 [131,132]. Comparing with chitinases isolated from terrestrial bacteria, marine chitinase exhibit better $\mathrm{pH}$ and salinity tolerance, which may represent promise for some special applications. Wang et al. [133] isolated marine Bacillus cereus that express two chitinases with optimum $\mathrm{pH}$, optimum temperature, $\mathrm{pH}$ stability, and thermal stability values of $9,50{ }^{\circ} \mathrm{C}, 3$ to $11,50{ }^{\circ} \mathrm{C}$ and $5,40{ }^{\circ} \mathrm{C}, 3$ to $11,60^{\circ} \mathrm{C}$, respectively. These enzymes retain $61 \%$, $60 \%, 73 \%$, and $100 \%$ as well as $60 \%, 60 \%, 71 \%$, and $96 \%$ of their original activity in the presence of $2 \%$ Tween 20, 2\% Tween 40, 2\% Triton X-100, and $1 \mathrm{mM} \mathrm{SDS}$, respectively [133]. The marine psychrophilic bacterium isolated by Stefanidi et al. from a sample raised from a depth of 1200 meters in the northern Pacific Ocean, secretes several chitinases in response to chitin induction. These chitinase genes encode a protein of 550 amino acids. The optimum $\mathrm{pH}$ and temperature of this chitinase are 5.0 and $28^{\circ} \mathrm{C}$, respectively. There are two crucial residues, Trp275 and Trp397, in the catalytic domain of the chitinase [134]. A chitinase directed mutagenesis study by Suginta et al. [134] revealed that Gly and Phe instead of Trp275 and Trp397, respectively, heavily altered the selection of $\beta$ substrate isomers. The Trp275 mutation alters the chitinase's kinetics characteristic features by increasing the catalytic constants $\left(k_{\mathrm{cat}}\right)$ and the specificity $\left(k_{\mathrm{cat}} / K_{\mathrm{M}}\right)$ of all substrates 5 - to 10 -fold. In contrast, the Trp397 mutation decreases the strength of binding between chitinase and substrate and the rate of soluble substrate degradation. 


\subsection{Prospects for Chitinase}

The degradation of chitin into oligosaccharides has promise that may be useful in numerous biological functions, such as antimicrobial activity and antitumor activity [135]. At present, chitooligosaccharides are mainly produced through chemical reactions in industry. This process has many drawbacks, such as the production of a series of unexpected short strain oligosaccharides. Moreover, chemical reactions can easily cause serious environmental pollution. Comparatively, biological degradation using chitinase has many advantages, such as being environmentally friendly, inexpensive and repeatable. Because of these advantages, the use of chitinase to hydrolyze chitin has drawn increasing attention during recent years.

\section{Cellulase}

\subsection{Introduction}

Cellulases are multi-component enzymes that can be divided into three components based on catalytic function, including endoglucanase (endo-1,4- $\beta$-D-glucanase, EC3.2.1.4), exoglucanase (exo-1,4- $\beta$-D-glucanase, EC3.2.1.91), and cellobiase ( $\beta$-1,4-glucosidase, EC3.2.1.21). Cellulases exhibit great potential in various applications, including papermaking, detergents, bioenergy and effluent treatment. Previous studies were limited to terrestrial-derived cellulases. As research on marine microbes and their enzymes advance, it was discovered that enzymes secreted by marine microbes possess several characteristic features, such as pressure tolerance, alkali resistance, cold resistance and heat resistance. As a result, marine cellulase resources have drawn increasing attention $[136,137]$.

\subsection{Marine Resources of Cellulase and Catalytic Mechanisms}

Thermophiles and cryophiles are two main types of marine microbes in the research of cellulose. For example, Rhodothermus marinus and Thermotoga neapolitana are well characterized. Extreme thermophile cellulose is composed of several domains. The cellulose and hemi-cellulase domains are catalytic domains that are linked by several cellulose binding domains (CBDs) [138]. Rhodothermus marinus express a type of cellulose with an optimal temperature that is greater than $90^{\circ} \mathrm{C}$. Bioinformatics and three-dimensional structure comparisons suggest that the aromatic amino acid cluster exposed on the surface of the protein is responsible for its thermophile activity [139]. Hakamada and coworkers [140] analyzed the structures of thermophile cellulose and alkali cellulose and revealed that three lysines located at 137, 179 and 194 are responsible for heat resistance. Moreover, they also demonstrated that increases in arginine, histidine and glutamine residues and decreases in aspartate and lysine residues are also related with alkali cellulose stability. Pseudoalteromonas sp. is another species gaining considerable attention. The optimal temperature of its cellulose, which ranges from 45 to $60^{\circ} \mathrm{C}$, is lower than that of other microbial celluloses. Lee and his partner [141] isolated a type of marine bacteria Bacillus subtilis. The optimal temperature of its cellulose is $50{ }^{\circ} \mathrm{C}$, and the optimum reaction $\mathrm{pH}$ is 6.5. Alfredsson reported on the marine bacteria Rhodothermus marinus isolated from alkaline underwater hot springs in Iceland. The optimum growth conditions of the enzyme are $65{ }^{\circ} \mathrm{C}, \mathrm{pH} 7.0$ and $2 \% \mathrm{NaCl}$ [142]. Trivedi [143] reported on Bacillus flexus from alga that produces alkaline cellulose. The molecular mass of the cellulose is $97 \mathrm{kDa}$, and good stability is noted at $\mathrm{pH}$ ranges of 9.0 to 12.0 . Moreover, approximately $70 \%$ of activity is maintained in $15 \% \mathrm{NaCl}$. Fellerand and his co-workers [51] isolated the psychrophilic filamentous bacterium near the Zhongshan Station and the Great Wall Station. This species produces cellulase and decomposes cellulase at 0 or $5^{\circ} \mathrm{C}$, thus maintaining proliferation at low temperatures [51]. Recently, Fang [144] identified a $\beta$-glucosidase gene named $b g l 1 A$ from a marine microbial metagenomic library by functional screening. This gene permitted tolerance of high glucose concentrations. The protein BgllA was identified as a member of the glycoside hydrolase 1 family. The recombinant $\beta$-glucosidase Bgl1A exhibited a high level of stability in the presence of various cations and high concentrations of $\mathrm{NaCl}$. The protein was activated by glucose with low concentrations. The enzymatic activity of Bgl1A was gradually inhibited by increasing concentrations of glucose, but $50 \%$ of the original value remained even in up to $1000 \mathrm{mM}$ glucose. 


\subsection{Prospects for Cellulase}

Cellulases from marine microorganisms exhibit activities under extreme conditions, such as high salt, high pressure, $\mathrm{pH}$ and high/low temperature. Thus, microorganisms abundant in the unique marine environment provide an important material base for exploiting new source of cellulases. For example, alkaline cellulose is used in the detergent industry. Moreover, alkaline celluloses exhibit more advantages in the disposal of sewage from spinning, papermaking, pickling and sauce production. Moreover, laundry processes require cellulases with the properties of alkali resistance, heat resistance and insensitivity to surfactants to simultaneously cut losses in detergent processing, storing and transiting. With the rapid development of the seaweed industry, there is an enormous demand for cellulases used in algae wall solutions and degradation of algae processing wastes. With the development of biotechnologies, especially bioinformatics and metagenomics, we believe that more cellulases with important functions that were previously unable to be discovered will be exploited in the future.

\section{Conclusions}

Marine microorganisms contain a series of novel and studied enzymes. However, due to limitations of exploration, a large proportion of these organisms have not been identified. This review presents several classic methods for enzyme transcriptional regulation and engineering, which can be used in marine microbial enzyme exploration. Additionally, this review describes the mechanism and current status of several polysaccharide-degrading enzymes. Hopefully, these novel strategies and well-studied catalytic mechanisms can serve as a reference for identifying novel enzymes from marine environments.

Acknowledgments: This work was supported by projects from the National Natural Science Foundation of China (No. 41276141, 41506160 and 31571970).

Conflicts of Interest: The authors declare no conflict of interest.

\section{References}

1. Antranikian, G.; Vorgias, C.E.; Bertoldo, C. Extreme environments as a resource for microorganisms and novel biocatalysts. Adv. Biochem. Eng. Biotechnol. 2005, 96, 219-262. [PubMed]

2. Bhattacharya, A.; Pletschke, B.I. Review of the enzymatic machinery of Halothermothrix orenii with special reference to industrial applications. Enzyme Microb. Technol. 2014, 55, 159-169. [CrossRef] [PubMed]

3. Liu, X.; Huang, Z.; Zhang, X.; Shao, Z.; Liu, Z. Cloning, expression and characterization of a novel cold-active and halophilic xylanase from Zunongwangia profunda. Extremophiles 2014, 18, 441-450. [CrossRef] [PubMed]

4. Jaiganesh, R.; Sampath Kumar, N.S. Marine bacterial sources of bioactive compounds. Adv. Food Nutr. Res. 2012, 65, 389-408. [PubMed]

5. Zotchev, S.B. Marine actinomycetes as an emerging resource for the drug development pipelines. J. Biotechnol. 2012, 158, 168-175. [CrossRef] [PubMed]

6. Lee, J.S.; Kim, Y.S.; Park, S.; Kim, J.; Kang, S.J.; Lee, M.H.; Ryu, S.; Choi, J.M.; Oh, T.K.; Yoon, J.H. Exceptional production of both prodigiosin and cycloprodigiosin as major metabolic constituents by a novel marine bacterium, Zooshikella rubidus S1-1. Appl. Environ. Microbiol. 2011, 77, 4967-4973. [CrossRef] [PubMed]

7. Martins, A.; Vieira, H.; Gaspar, H.; Santos, S. Marketed marine natural products in the pharmaceutical and cosmeceutical industries: Tips for success. Mar. Drugs 2014, 12, 1066-1101. [CrossRef] [PubMed]

8. Rahman, H.; Austin, B.; Mitchell, W.J.; Morris, P.C.; Jamieson, D.J.; Adams, D.R.; Spragg, A.M.; Schweizer, M. Novel anti-infective compounds from marine bacteria. Mar. Drugs 2010, 8, 498-518. [CrossRef] [PubMed]

9. Abdelmohsen, U.R.; Yang, C.; Horn, H.; Hajjar, D.; Ravasi, T.; Hentschel, U. Actinomycetes from Red Sea sponges: Sources for chemical and phylogenetic diversity. Mar. Drugs 2014, 12, 2771-2789. [CrossRef] [PubMed]

10. Komaki, H.; Ichikawa, N.; Hosoyama, A.; Fujita, N.; Igarashi, Y. Draft genome sequence of marine-derived streptomyces sp. TP-A0873, a producer of a pyrrolizidine alkaloid bohemamine. Genome Announc. 2015, 3. [CrossRef] [PubMed] 
11. Zhou, K.; Zhang, X.; Zhang, F.; Li, Z. Phylogenetically diverse cultivable fungal community and polyketide synthase (PKS), non-ribosomal peptide synthase (NRPS) genes associated with the South China Sea sponges. Microb. Ecol. 2011, 62, 644-654. [CrossRef] [PubMed]

12. Zhu, P.; Zheng, Y.; You, Y.; Yan, X.; Shao, J. Molecular phylogeny and modular structure of hybrid NRPS/PKS gene fragment of Pseudoalteromonas sp. NJ6-3-2 isolated from marine sponge Hymeniacidon perleve. J. Microbiol. Biotechnol. 2009, 19, 229-237. [PubMed]

13. Bassler, B.L. Cell-to-cell communication in bacteria: A chemical discourse. Harvey Lect. 2004, 100, $123-142$. [PubMed]

14. Miyamoto, C.M.; Meighen, E.A. Involvement of LuxR, a quorum sensing regulator in Vibrio harveyi, in the promotion of metabolic genes: $\arg A, \operatorname{purM}, \operatorname{lys} E$ and rluA. Biochim. Biophys. Acta 2006, 1759, $296-307$. [CrossRef] [PubMed]

15. Choudhary, S.; Schmidt-Dannert, C. Applications of quorum sensing in biotechnology. Appl. Microbiol. Biotechnol. 2010, 86, 1267-1279. [CrossRef] [PubMed]

16. Mangwani, N.; Dash, H.R.; Chauhan, A.; Das, S. Bacterial quorum sensing: Functional features and potential applications in biotechnology. J. Mol. Microbiol. Biotechnol. 2012, 22, 215-227. [CrossRef] [PubMed]

17. Liu, D.; Momb, J.; Thomas, P.W.; Moulin, A.; Petsko, G.A.; Fast, W.; Ringe, D. Mechanism of the quorum-quenching lactonase (AiiA) from Bacillus thuringiensis. 1. Product-bound structures. Biochemistry 2008, 47, 7706-7714. [CrossRef] [PubMed]

18. Momb, J.; Wang, C.; Liu, D.; Thomas, P.W.; Petsko, G.A.; Guo, H.; Ringe, D.; Fast, W. Mechanism of the quorum-quenching lactonase (AiiA) from Bacillus thuringiensis. 2. Substrate modeling and active site mutations. Biochemistry 2008, 47, 7715-7725. [CrossRef] [PubMed]

19. Thomas, P.W.; Stone, E.M.; Costello, A.L.; Tierney, D.L.; Fast, W. The quorum-quenching lactonase from Bacillus thuringiensis is a metalloprotein. Biochemistry 2005, 44, 7559-7569. [CrossRef] [PubMed]

20. Cao, Y.; He, S.; Zhou, Z.; Zhang, M.; Mao, W.; Zhang, H.; Yao, B. Orally administered thermostable N-acyl homoserine lactonase from Bacillus sp. strain AI96 attenuates Aeromonas hydrophila infection in zebrafish. Appl. Environ. Microbiol. 2012, 78, 1899-1908. [CrossRef] [PubMed]

21. Chen, R.; Zhou, Z.; Cao, Y.; Bai, Y.; Yao, B. High yield expression of an AHL-lactonase from Bacillus sp. B546 in Pichia pastoris and its application to reduce Aeromonas hydrophila mortality in aquaculture. Microb. Cell Fact. 2010, 9, 39. [CrossRef] [PubMed]

22. Carlier, A.; Uroz, S.; Smadja, B.; Fray, R.; Latour, X.; Dessaux, Y.; Faure, D. The Ti plasmid of Agrobacterium tumefaciens harbors an attM-paralogous gene, aiiB, also encoding $N$-Acyl homoserine lactonase activity. Appl. Environ. Microbiol. 2003, 69, 4989-4893. [CrossRef] [PubMed]

23. Park, S.Y.; Lee, S.J.; Oh, T.K.; Oh, J.W.; Koo, B.T.; Yum, D.Y.; Lee, J.K. AhlD, an N-acylhomoserine lactonase in Arthrobacter sp., and predicted homologues in other bacteria. Microbiology 2003, 149, 1541-1550. [CrossRef] [PubMed]

24. Uroz, S.; Oger, P.M.; Chapelle, E.; Adeline, M.T.; Faure, D.; Dessaux, Y. A Rhodococcus qsdA-encoded enzyme defines a novel class of large-spectrum quorum-quenching lactonases. Appl. Environ. Microbiol. 2008, 74, 1357-1366. [CrossRef] [PubMed]

25. Wang, W.Z.; Morohoshi, T.; Ikenoya, M.; Someya, N.; Ikeda, T. AiiM, a novel class of N-acylhomoserine lactonase from the leaf-associated bacterium Microbacterium testaceum. Appl. Environ. Microbiol. 2010, 76, 2524-2530. [CrossRef] [PubMed]

26. Zhang, H.B.; Wang, L.H.; Zhang, L.H. Genetic control of quorum-sensing signal turnover in Agrobacterium tumefaciens. Proc. Natl. Acad. Sci. USA 2002, 99, 4638-4643. [CrossRef] [PubMed]

27. Gao, A.; Mei, G.Y.; Liu, S.; Wang, P.; Tang, Q.; Liu, Y.P.; Wen, H.; An, X.M.; Zhang, L.Q.; Yan, X.X.; et al. High-resolution structures of AidH complexes provide insights into a novel catalytic mechanism for $N$-acyl homoserine lactonase. Acta Crystallogr. D Biol. Crystallogr. 2013, 69, 82-91. [CrossRef] [PubMed]

28. Mei, G.Y.; Yan, X.X.; Turak, A.; Luo, Z.Q.; Zhang, L.Q. AidH, an alpha/beta-hydrolase fold family member from an Ochrobactrum sp. strain, is a novel $N$-acylhomoserine lactonase. Appl. Environ. Microbiol. 2010, 76, 4933-4942. [CrossRef] [PubMed]

29. Tang, K.; Su, Y.; Brackman, G.; Cui, F.; Zhang, Y.; Shi, X.; Coenye, T.; Zhang, X.H. MomL, a novel marine-derived $\mathrm{N}$-acyl homoserine lactonase from Muricauda olearia. Appl. Environ. Microbiol. 2015, 81, 774-782. [CrossRef] [PubMed] 
30. Huang, W.; Lin, Y.; Yi, S.; Liu, P.; Shen, J.; Shao, Z.; Liu, Z. QsdH, a novel AHL lactonase in the RND-type inner membrane of marine Pseudoalteromonas byunsanensis strain 1A01261. PLoS ONE 2012, 7, e46587. [CrossRef] [PubMed]

31. Tang, K.; Zhang, Y.; Yu, M.; Shi, X.; Coenye, T.; Bossier, P.; Zhang, X.H. Evaluation of a new high-throughput method for identifying quorum quenching bacteria. Sci. Rep. 2013, 3, 2935. [CrossRef] [PubMed]

32. Gao, X.; Xie, X.; Pashkov, I.; Sawaya, M.R.; Laidman, J.; Zhang, W.; Cacho, R.; Yeates, T.O.; Tang, Y. Directed evolution and structural characterization of a simvastatin synthase. Chem. Biol. 2009, 16, 1064-1074. [CrossRef] [PubMed]

33. Sullivan, R.F.; Holtman, M.A.; Zylstra, G.J.; White, J.F.; Kobayashi, D.Y. Taxonomic positioning of two biological control agents for plant diseases as Lysobacter enzymogenes based on phylogenetic analysis of 16S rDNA, fatty acid composition and phenotypic characteristics. J. Appl. Microbiol. 2003, 94, 1079-1086. [CrossRef] [PubMed]

34. Wang, Y.; Qian, G.; Li, Y.; Wright, S.; Shen, Y.; Liu, F.; Du, L. Biosynthetic mechanism for sunscreens of the biocontrol agent Lysobacter enzymogenes. PLoS ONE 2013, 8, e66633. [CrossRef] [PubMed]

35. Xie, Y.; Wright, S.; Shen, Y.; Du, L. Bioactive natural products from Lysobacter. Nat. Prod. Rep. 2012, 29, 1277-1287. [CrossRef] [PubMed]

36. Wang, Y.; Qian, G.; Liu, F.; Li, Y.Z.; Shen, Y.; Du, L. Facile method for site-specific gene integration in Lysobacter enzymogenes for yield improvement of the anti-MRSA antibiotics WAP-8294A and the antifungal antibiotic HSAF. ACS Synth. Biol. 2013, 2, 670-678. [CrossRef] [PubMed]

37. Zhang, W.; Li, Y.; Qian, G.; Wang, Y.; Chen, H.; Li, Y.Z.; Liu, F.; Shen, Y.; Du, L. Identification and characterization of the anti-methicillin-resistant Staphylococcus aureus WAP-8294A2 biosynthetic gene cluster from Lysobacter enzymogenes OH11. Antimicrob. Agents Chemother. 2011, 55, 5581-5589. [CrossRef] [PubMed]

38. Lou, L.; Qian, G.; Xie, Y.; Hang, J.; Chen, H.; Zaleta-Rivera, K.; Li, Y.; Shen, Y.; Dussault, P.H.; Liu, F.; et al. Biosynthesis of HSAF, a tetramic acid-containing macrolactam from Lysobacter enzymogenes. J. Am. Chem. Soc. 2011, 133, 643-645. [CrossRef] [PubMed]

39. Yu, F.; Zaleta-Rivera, K.; Zhu, X.; Huffman, J.; Millet, J.C.; Harris, S.D.; Yuen, G.; Li, X.C.; Du, L. Structure and biosynthesis of heat-stable antifungal factor (HSAF), a broad-spectrum antimycotic with a novel mode of action. Antimicrob. Agents Chemother. 2007, 51, 64-72. [CrossRef] [PubMed]

40. Han, Y.; Wang, Y.; Tombosa, S.; Wright, S.; Huffman, J.; Yuen, G.; Qian, G.; Liu, F.; Shen, Y.; Du, L. Identification of a small molecule signaling factor that regulates the biosynthesis of the antifungal polycyclic tetramate macrolactam HSAF in Lysobacter enzymogenes. Appl. Microbiol. Biotechnol. 2015, 99, 801-811. [CrossRef] [PubMed]

41. Di Cagno, R.; De Angelis, M.; Calasso, M.; Gobbetti, M. Proteomics of the bacterial cross-talk by quorum sensing. J. Proteom. 2011, 74, 19-34. [CrossRef] [PubMed]

42. Dong, Y.H.; Zhang, L.H. Quorum sensing and quorum-quenching enzymes. J. Microbiol. 2005, 43, $101-109$. [PubMed]

43. Martino, P.D.; Fursy, R.; Bret, L.; Sundararaju, B.; Phillips, R.S. Indole can act as an extracellular signal to regulate biofilm formation of Escherichia coli and other indole-producing bacteria. Can. J. Microbiol. 2003, 49, 443-449. [CrossRef] [PubMed]

44. Meiser, P.; Bode, H.B.; Muller, R. The unique DKxanthene secondary metabolite family from the myxobacterium Myxococcus xanthus is required for developmental sporulation. Proc. Natl. Acad. Sci. USA 2006, 103, 19128-19133. [CrossRef] [PubMed]

45. Poplawsky, A.R.; Walters, D.M.; Rouviere, P.E.; Chun, W. A gene for a dioxygenase-like protein determines the production of the DF signal in Xanthomonas campestris pv. campestris. Mol. Plant. Pathol. 2005, 6, 653-657. [CrossRef] [PubMed]

46. Stevens, A.M.; Queneau, Y.; Soulere, L.; von Bodman, S.; Doutheau, A. Mechanisms and synthetic modulators of AHL-dependent gene regulation. Chem. Rev. 2011, 111, 4-27. [CrossRef] [PubMed]

47. Guzman-Maldonado, H.; Paredes-Lopez, O. Amylolytic enzymes and products derived from starch: A review. Crit. Rev. Food Sci. Nutr. 1995, 35, 373-403. [CrossRef] [PubMed]

48. Song, Q.; Wang, Y.; Yin, C.; Zhang, X.H. LaaA, a novel high-active alkalophilic alpha-amylase from deep-sea bacterium Luteimonas abyssi XH031(T). Enzyme Microb. Technol. 2016, 90, 83-92. [CrossRef] [PubMed]

49. Sibakov, M.; Palva, I. Isolation and the 5 '-end nucleotide sequence of Bacillus licheniformis alpha-amylase gene. Eur. J. Biochem. 1984, 145, 567-572. [CrossRef] [PubMed] 
50. Takkinen, K.; Pettersson, R.F.; Kalkkinen, N.; Palva, I.; Soderlund, H.; Kaariainen, L. Amino acid sequence of alpha-amylase from Bacillus amyloliquefaciens deduced from the nucleotide sequence of the cloned gene. J. Biol. Chem. 1983, 258, 1007-1013. [PubMed]

51. Feller, G.; Payan, F.; Theys, F.; Qian, M.; Haser, R.; Gerday, C. Stability and structural analysis of alpha-amylase from the antarctic psychrophile Alteromonas haloplanctis A23. Eur. J. Biochem. 1994, 222, 441-447. [CrossRef] [PubMed]

52. Hagihara, H.; Igarashi, K.; Hayashi, Y.; Endo, K.; Ikawa-Kitayama, K.; Ozaki, K.; Kawai, S.; Ito, S. Novel alpha-amylase that is highly resistant to chelating reagents and chemical oxidants from the alkaliphilic Bacillus isolate KSM-K38. Appl. Environ. Microb. 2001, 67, 1744-1750. [CrossRef] [PubMed]

53. Wang, N.; Zhang, Y.; Wang, Q.; Liu, J.; Wang, H.; Xue, Y.; Ma, Y. Gene cloning and characterization of a novel alpha-amylase from alkaliphilic Alkalimonas amylolytica. Biotechnol. J. 2006, 1, 1258-1265. [CrossRef] [PubMed]

54. Lee, S.P.; Morikawa, M.; Takagi, M.; Imanaka, T. Cloning of the aapT gene and characterization of its product, alpha-amylase-pullulanase (AapT), from thermophilic and alkaliphilic Bacillus sp. strain XAL601. Appl. Environ. Microbiol. 1994, 60, 3764-3773. [PubMed]

55. Igarashi, K.; Hatada, Y.; Hagihara, H.; Saeki, K.; Takaiwa, M.; Uemura, T.; Ara, K.; Ozaki, K.; Kawai, S.; Kobayashi, T.; et al. Enzymatic properties of a novel liquefying alpha-amylase from an alkaliphilic Bacillus isolate and entire nucleotide and amino acid sequences. Appl. Environ. Microbiol. 1998, 64, 3282-3289. [PubMed]

56. Zhang, J.W.; Zeng, R.Y. Purification and characterization of a cold-adapted alpha-amylase produced by Nocardiopsis sp. 7326 isolated from Prydz Bay, Antarctic. Mar. Biotechnol. 2008, 10, 75-82. [CrossRef] [PubMed]

57. Kim, T.U.; Gu, B.G.; Jeong, J.Y.; Byun, S.M.; Shin, Y.C. Purification and characterization of a maltotetraoseforming alkaline (alpha)-amylase from an alkalophilic Bacillus Strain, GM8901. Appl. Environ. Microbiol. 1995, 61, 3105-3112. [PubMed]

58. Boyer, E.W.; Ingle, M.B. Extracellular alkaline amylase from a Bacillus species. J. Bacteriol. 1972, 110, $992-1000$. [PubMed]

59. Sharma, A.; Satyanarayana, T. Cloning and expression of acidstable, high maltose-forming, $\mathrm{Ca}^{2+}$-independent alpha-amylase from an acidophile Bacillus acidicola and its applicability in starch hydrolysis. Extremophiles 2012, 16, 515-522. [CrossRef] [PubMed]

60. Prieto, J.A.; Bort, B.R.; Martinez, J.; Randezgil, F.; Buesa, C.; Sanz, P. Purification and characterization of a new alpha-amylase of intermediate thermal-stability from the yeast Lipomyces kononenkoae. Biochem. Cell Biol. 1995, 73, 41-49. [CrossRef] [PubMed]

61. Schwermann, B.; Pfau, K.; Liliensiek, B.; Schleyer, M.; Fischer, T.; Bakker, E.P. Purification, properties and structural aspects of a thermoacidophilic alpha-amylase from Alicyclobacillus acidocaldarius atcc 27009. Insight into acidostability of proteins. Eur. J. Biochem. 1994, 226, 981-991. [CrossRef] [PubMed]

62. Asoodeh, A.; Chamani, J.; Lagzian, M. A novel thermostable, acidophilic alpha-amylase from a new thermophilic "Bacillus sp. Ferdowsicous" isolated from Ferdows hot mineral spring in Iran: Purification and biochemical characterization. Int. J. Biol. Macromol. 2010, 46, 289-297. [PubMed]

63. Buonocore, V.; Caporale, C.; De Rosa, M.; Gambacorta, A. Stable, inducible thermoacidophilic alpha-amylase from Bacillus acidocaldarius. J. Bacteriol. 1976, 128, 515-521. [PubMed]

64. Ali, I.; Akbar, A.; Anwar, M.; Prasongsuk, S.; Lotrakul, P.; Punnapayak, H. Purification and characterization of a polyextremophilic alpha-amylase from an obligate halophilic Aspergillus penicillioides isolate and its potential for souse with detergents. Biomed. Res. Int. 2015. [CrossRef] [PubMed]

65. Xian, L.; Wang, F.; Luo, X.; Feng, Y.L.; Feng, J.X. Purification and characterization of a highly efficient calcium-independent alpha-amylase from Talaromyces pinophilus 1-95. PLoS ONE 2015, 10, e0121531. [CrossRef] [PubMed]

66. Wang, S.; Lu, Z.; Lu, M.; Qin, S.; Liu, H.; Deng, X.; Lin, Q.; Chen, J. Identification of archaeon-producing hyperthermophilic alpha-amylase and characterization of the alpha-amylase. Appl. Microbiol. Biotechnol. 2008, 80, 605-614. [CrossRef] [PubMed]

67. Han, P.; Zhou, P.; Hu, S.Q.; Yang, S.Q.; Yan, Q.J.; Jiang, Z.Q. A novel multifunctional alpha-amylase from the thermophilic fungus Malbranchea cinnamomea: Biochemical characterization and three-dimensional structure. Appl. Biochem. Biotechnol. 2013, 170, 420-435. [CrossRef] [PubMed] 
68. Silva, T.M.; Damasio, A.R.; Maller, A.; Michelin, M.; Squina, F.M.; Jorge, J.A.; Polizeli Mde, L. Purification, partial characterization, and covalent immobilization-stabilization of an extracellular alpha-amylase from Aspergillus niveus. Folia Microbiol. 2013, 58, 495-502. [CrossRef] [PubMed]

69. El-Sayed, A.K.; Abou Dobara, M.I.; El-Fallal, A.A.; Omar, N.F. Purification, sequencing, and biochemical characterization of a novel calcium-independent alpha-amylase AmyTVE from Thermoactinomyces vulgaris. Appl. Biochem. Biotechnol. 2013, 170, 483-497. [CrossRef] [PubMed]

70. Kim, D.H.; Morimoto, N.; Saburi, W.; Mukai, A.; Imoto, K.; Takehana, T.; Koike, S.; Mori, H.; Matsui, H. Purification and characterization of a liquefying alpha-amylase from alkalophilic thermophilic Bacillus sp. AAH-31. Biosci. Biotechnol. Biochem. 2012, 76, 1378-1383. [CrossRef] [PubMed]

71. Michelin, M.; Silva, T.M.; Benassi, V.M.; Peixoto-Nogueira, S.C.; Moraes, L.A.; Leao, J.M.; Jorge, J.A.; Terenzi, H.F.; Polizeli Mde, L. Purification and characterization of a thermostable alpha-amylase produced by the fungus Paecilomyces variotii. Carbohydr. Res. 2010, 345, 2348-2353. [CrossRef] [PubMed]

72. Lu, M.; Wang, S.; Fang, Y.; Li, H.; Liu, S.; Liu, H. Cloning, expression, purification, and characterization of cold-adapted alpha-amylase from Pseudoalteromonas arctica GS230. Protein J. 2010, 29, 591-597. [CrossRef] [PubMed]

73. Liu, X.D.; Xu, Y. A novel raw starch digesting alpha-amylase from a newly isolated Bacillus sp. YX-1: Purification and characterization. Bioresour. Technol. 2008, 99, 4315-4320. [CrossRef] [PubMed]

74. Uma Maheswar Rao, J.L.; Satyanarayana, T. Purification and characterization of a hyperthermostable and high maltogenic alpha-amylase of an extreme thermophile Geobacillus thermoleovorans. Appl. Biochem. Biotechnol. 2007, 142, 179-193. [CrossRef] [PubMed]

75. Champreda, V.; Kanokratana, P.; Sriprang, R.; Tanapongpipat, S.; Eurwilaichitr, L. Purification, biochemical characterization, and gene cloning of a new extracellular thermotolerant and glucose tolerant maltooligosaccharide-forming alpha-amylase from an endophytic ascomycete Fusicoccum sp. BCC4124. Biosci. Biotechnol. Biochem. 2007, 71, 2010-2020. [CrossRef] [PubMed]

76. Nagarajan, D.R.; Rajagopalan, G.; Krishnan, C. Purification and characterization of a maltooligosaccharideforming alpha-amylase from a new Bacillus subtilis KCC103. Appl. Microbiol. Biotechnol. 2006, 73, 591-597. [CrossRef] [PubMed]

77. Najafi, M.F.; Deobagkar, D.; Deobagkar, D. Purification and characterization of an extracellular alpha-amylase from Bacillus subtilis AX20. Protein Expr. Purif. 2005, 41, 349-354. [CrossRef] [PubMed]

78. Mijts, B.N.; Patel, B.K. Cloning, sequencing and expression of an alpha-amylase gene, amyA, from the thermophilic halophile Halothermothrix orenii and purification and biochemical characterization of the recombinant enzyme. Microbiology 2002, 148, 2343-2349. [CrossRef] [PubMed]

79. Chakraborty, K.; Bhattacharyya, B.K.; Sen, S.K. Purification and characterization of a thermostable alpha-amylase from Bacillus stearothermophilus. Folia Microbiol. 2000, 45, 207-210. [CrossRef]

80. Egas, M.C.; da Costa, M.S.; Cowan, D.A.; Pires, E.M. Extracellular alpha-amylase from Thermus filiformis Ork A2: Purification and biochemical characterization. Extremophiles 1998, 2, 23-32. [CrossRef] [PubMed]

81. Marco, J.L.; Bataus, L.A.; Valencia, F.F.; Ulhoa, C.J.; Astolfi-Filho, S.; Felix, C.R. Purification and characterization of a truncated Bacillus subtilis alpha-amylase produced by Escherichia coli. Appl. Microbiol. Biotechnol. 1996, 44, 746-752. [PubMed]

82. Shih, N.J.; Labbe, R.G. Purification and characterization of an extracellular alpha-amylase from Clostridium perfringens type A. Appl. Environ. Microbiol. 1995, 61, 1776-1779. [PubMed]

83. Spiess, C.; Happersberger, H.P.; Glocker, M.O.; Spiess, E.; Rippe, K.; Ehrmann, M. Biochemical characterization and mass spectrometric disulfide bond mapping of periplasmic alpha-amylase MalS of Escherichia coli. J. Biol. Chem. 1997, 272, 22125-22133. [CrossRef] [PubMed]

84. Mantsala, P.; Zalkin, H. Membrane-bound and soluble extracellular alpha-amylase from Bacillus subtilis. J. Biol. Chem. 1979, 254, 8540-8547. [PubMed]

85. Buisson, G.; Duee, E.; Haser, R.; Payan, F. Three dimensional structure of porcine pancreatic alpha-amylase at $2.9 \AA$ resolution. Role of calcium in structure and activity. EMBO J. 1987, 6, 3909-3916. [PubMed]

86. Nielsen, J.E.; Borchert, T.V. Protein engineering of bacterial $\alpha$-amylases. Biochim. Biophys. Acta 2000, 1543, 253-274. [CrossRef]

87. Tang, S.Y.; Le, Q.T.; Shim, J.H.; Yang, S.J.; Auh, J.H.; Park, C.; Park, K.H. Enhancing thermostability of maltogenic amylase from Bacillus thermoalkalophilus ET2 by DNA shuffling. FEBS J. 2006, 273, 3335-3345. [CrossRef] [PubMed] 
88. Tomazic, S.J.; Klibanov, A.M. Mechanisms of irreversible thermal inactivation of Bacillus alpha-amylases. J. Biol. Chem. 1988, 263, 3086-3091. [PubMed]

89. Vallee, B.L.; Stein, E.A.; Sumerwell, W.N.; Fischer, E.H. Metal content of alpha-amylases of various origins. J. Biol. Chem. 1959, 234, 2901-2905. [PubMed]

90. Machius, M.; Declerck, N.; Huber, R.; Wiegand, G. Activation of Bacillus licheniformis alpha-amylase through a disorder-order transition of the substrate-binding site mediated by a calcium-sodium-calcium metal triad. Structure 1998, 6, 281-292. [CrossRef]

91. Machius, M.; Wiegand, G.; Huber, R. Crystal structure of calcium-depleted Bacillus licheniformis alpha-amylase at $2.2 \AA$ resolution. J. Mol. Biol. 1995, 246, 545-559. [CrossRef] [PubMed]

92. Li, L.; Yang, J.; Li, J.; Long, L.; Xiao, Y.; Tian, X.; Wang, F.; Zhang, S. Role of two amino acid residues' insertion on thermal stability of thermophilic alpha-amylase AMY121 from a deep sea bacterium Bacillus sp. SCSIO 15121. Bioprocess Biosyst. Eng. 2014, 38, 871-879. [CrossRef] [PubMed]

93. Ghollasi, M.; Khajeh, K.; Naderi-Manesh, H.; Ghasemi, A. Engineering of a Bacillus alpha-amylase with improved thermostability and calcium independency. Appl. Biochem. Biotechnol. 2010, 162, 444-459. [CrossRef] [PubMed]

94. Ben Ali, M.; Khemakhem, B.; Robert, X.; Haser, R.; Bejar, S. Thermostability enhancement and change in starch hydrolysis profile of the maltohexaose-forming amylase of Bacillus stearothermophilus US100 strain. Biochem. J. 2006, 394, 51-56. [CrossRef] [PubMed]

95. Khemakhem, B.; Ben Ali, M.; Aghajari, N.; Juy, M.; Haser, R.; Bejar, S. The importance of an extra loop in the B-domain of an alpha-amylase from B. stearothermophilus US100. Biochem. Biophys. Res. Commun. 2009, 385, 78-83. [CrossRef] [PubMed]

96. Binter, A.; Staunig, N.; Jelesarov, I.; Lohner, K.; Palfey, B.A.; Deller, S.; Gruber, K.; Macheroux, P. A single intersubunit salt bridge affects oligomerization and catalytic activity in a bacterial quinone reductase. FEBS J. 2009, 276, 5263-5274. [CrossRef] [PubMed]

97. Liu, Y.H.; Lu, F.P.; Li, Y.; Wang, J.L.; Gao, C. Acid stabilization of Bacillus licheniformis alpha amylase through introduction of mutations. Appl. Microbiol. Biotechnol. 2008, 80, 795-803. [CrossRef] [PubMed]

98. Yang, G.; Bai, A.; Gao, L.; Zhang, Z.; Zheng, B.; Feng, Y. Glu88 in the non-catalytic domain of acylpeptide hydrolase plays dual roles: Charge neutralization for enzymatic activity and formation of salt bridge for thermodynamic stability. Biochim. Biophys. Acta 2009, 1794, 94-102. [CrossRef] [PubMed]

99. Yang, H.; Liu, L.; Shin, H.D.; Chen, R.R.; Li, J.; Du, G.; Chen, J. Structure-based engineering of histidine residues in the catalytic domain of alpha-amylase from Bacillus subtilis for improved protein stability and catalytic efficiency under acidic conditions. J. Biotechnol. 2013, 164, 59-66. [CrossRef] [PubMed]

100. Haghani, K.; Khajeh, K.; Naderi-Manesh, H.; Ranjbar, B. Evidence regarding the hypothesis that the histidine-histidine contact pairs may affect protein stability. Int. J. Biol. Macromol. 2012, 50, 1040-1047. [CrossRef] [PubMed]

101. Wong, T.Y.; Preston, L.A.; Schiller, N.L. ALGINATE LYASE: Review of major sources and enzyme characteristics, structure-function analysis, biological roles, and applications. Annu. Rev. Microbiol. 2000, 54, 289-340. [CrossRef] [PubMed]

102. Tseng, C.-H.; Yamaguchi, K.; Kitamikado, M. Two types of alginate lyase from a marine bacterium Vibrio sp. Al-9. Nippon Suisan Gakkaishi 1992, 58, 743-749. [CrossRef]

103. Tseng, C.-H.; Yamaguchi, K.; Kitamikado, M. Isolation and some properties of alginate lyase from a marine bacterium Vibrio sp. Al-128. Nippon Suisan Gakkaishi 1992, 58, 533-538. [CrossRef]

104. Song, Y.; Yu, W.G.; Han, F.; Han, W.J.; Li, J.B. Purification and characterization of aginate lyase from marine bacterium Vibrio sp. QY101. Acta Biochim. Biophys. Sin. 2003, 35, 473-477. [PubMed]

105. Han, F.; Gong, Q.H.; Song, K.; Li, J.B.; Yu, W.G. Cloning, sequence analysis and expression of gene alyVI encoding alginate lyase from marine bacterium Vibrio sp. QY101. DNA Seq. 2004, 15, 344-350. [CrossRef] [PubMed]

106. Takeshita, S.; Sato, N.; Igarashi, M.; Muramatsu, T. A highly denaturant-durable alginate Lyase from a marine bacterium: Purification and properties. Biosci. Biotechnol. Biochem. 1993, 57, 1125-1128. [CrossRef] [PubMed]

107. Liu, G.; Yue, L.; Chi, Z.; Yu, W.; Madzak, C. The surface display of the alginate lyase on the cells of Yarrowia lipolytica for hydrolysis of alginate. Mar. Biotechnol. 2009, 11, 619-626. [CrossRef] [PubMed] 
108. Li, L.; Jiang, X.; Guan, H.; Wang, P.; Guo, H. Three alginate lyases from marine bacterium Pseudomonas fluorescens HZJ216: Purification and characterization. Appl. Biochem. Biotechnol. 2011, 164, 305-317. [CrossRef] [PubMed]

109. Dong, S.; Yang, J.; Zhang, X.Y.; Shi, M.; Song, X.Y.; Chen, X.L.; Zhang, Y.Z. Cultivable alginate lyase-excreting bacteria associated with the Arctic brown alga Laminaria. Mar. Drugs 2012, 10, 2481-2491. [CrossRef] [PubMed]

110. Rahman, M.M.; Inoue, A.; Tanaka, H.; Ojima, T. cDNA cloning of an alginate lyase from a marine gastropod Aplysia kurodai and assessment of catalytically important residues of this enzyme. Biochimie 2011, 93, 1720-1730. [CrossRef] [PubMed]

111. MacDonald, L.C.; Berger, B.W. A polysaccharide lyase from Stenotrophomonas maltophilia with a unique, pH-regulated substrate specificity. J. Biol. Chem. 2014, 289, 312-325. [CrossRef] [PubMed]

112. Kobayashi, T.; Uchimura, K.; Miyazaki, M.; Nogi, Y.; Horikoshi, K. A new high-alkaline alginate lyase from a deep-sea bacterium Agarivorans sp. Extremophiles 2009, 13, 121-129. [CrossRef] [PubMed]

113. Miyake, O.; Ochiai, A.; Hashimoto, W.; Murata, K. Origin and diversity of alginate lyases of families PL-5 and -7 in Sphingomonas sp. strain A1. J. Bacteriol. 2004, 186, 2891-2896. [CrossRef] [PubMed]

114. Osawa, T.; Matsubara, Y.; Muramatsu, T.; Kimura, M.; Kakuta, Y. Crystal structure of the alginate (poly alpha-L-guluronate) lyase from Corynebacterium sp. at $1.2 \AA$ resolution. J. Mol. Biol. 2005, 345, 1111-1118. [CrossRef] [PubMed]

115. Duan, G.; Han, F.; Yu, W. Cloning, sequence analysis, and expression of gene alyPI encoding an alginate lyase from marine bacterium Pseudoalteromonas sp. CY24. Can. J. Microbiol. 2009, 55, 1113-1118. [CrossRef] [PubMed]

116. Yamamoto, S.; Sahara, T.; Sato, D.; Kawasaki, K.; Ohgiya, S.; Inoue, A.; Ojima, T. Catalytically important amino-acid residues of abalone alginate lyase HdAly assessed by site-directed mutagenesis. Enzyme Microb. Technol. 2008, 43, 396-402. [CrossRef]

117. Zhu, B.; Yin, H. Alginate lyase: Review of major sources and classification, properties, structure-function analysis and applications. Bioengineered 2015, 6, 125-131. [CrossRef] [PubMed]

118. Matsushima, R.; Danno, H.; Uchida, M.; Ishihara, K.; Suzuki, T.; Kaneniwa, M.; Ohtsubo, Y.; Nagata, Y.; Tsuda, M. Analysis of extracellular alginate lyase and its gene from a marine bacterial strain, Pseudoalteromonas atlantica AR06. Appl. Microbiol. Biotechnol. 2010, 86, 567-576. [CrossRef] [PubMed]

119. Matsushima, R.; Watanabe, R.; Tsuda, M.; Suzuki, T. Analysis of extracellular alginate lyase (alyA) expression and its regulatory region in a marine bacterial strain, Pseudoalteromonas atlantica AR06, using a gfp gene reporter system. Mar. Biotechnol. 2013, 15, 349-356. [CrossRef] [PubMed]

120. Ashton, R.S.; Banerjee, A.; Punyani, S.; Schaffer, D.V.; Kane, R.S. Scaffolds based on degradable alginate hydrogels and poly(lactide-co-glycolide) microspheres for stem cell culture. Biomaterials 2007, 28, 5518-5525. [CrossRef] [PubMed]

121. Hoiby, N.; Bjarnsholt, T.; Givskov, M.; Molin, S.; Ciofu, O. Antibiotic resistance of bacterial biofilms. Int. J. Antimicrob. Agents 2010, 35, 322-332. [CrossRef] [PubMed]

122. Iehata, S.; Inagaki, T.; Okunishi, S.; Nakano, M.; Tanaka, R.; Maeda, H. Improved gut environment of abalone Haliotis gigantea through Pediococcus sp Ab1 treatment. Aquaculture 2010, 305, 59-65. [CrossRef]

123. Younes, I.; Rinaudo, M. Chitin and chitosan preparation from marine sources. Structure, properties and applications. Mar. Drugs 2015, 13, 1133-1174. [CrossRef] [PubMed]

124. Wang, S.; Shao, B.; Fu, H.; Rao, P. Isolation of a thermostable legume chitinase and study on the antifungal activity. Appl. Microbiol. Biotechnol. 2009, 85, 313-321. [CrossRef] [PubMed]

125. Hirono, I.; Yamashita, M.; Aoki, T. Note: Molecular cloning of chitinase genes from Vibrio anguillarum and V. parahaemolyticus. J. Appl. Microbiol. 1998, 84, 1175-1178. [CrossRef] [PubMed]

126. Aunpad, R.; Panbangred, W. Cloning and characterization of the constitutively expressed chitinase $C$ gene from a marine bacterium, Salinivibrio costicola strain 5SM-1. J. Biosci. Bioeng. 2003, 96, 529-536. [CrossRef]

127. Howard, M.B.; Ekborg, N.A.; Taylor, L.E.; Weiner, R.M.; Hutcheson, S.W. Genomic analysis and initial characterization of the chitinolytic system of Microbulbifer degradans strain 2-40. J. Bacteriol. 2003, 185, 3352-3360. [CrossRef] [PubMed]

128. Tsujibo, H.; Kubota, T.; Yamamoto, M.; Miyamoto, K.; Inamori, Y. Characterization of chitinase genes from an alkaliphilic actinomycete, Nocardiopsis prasina OPC-131. Appl. Environ. Microbiol. 2003, 69, 894-900. [CrossRef] [PubMed] 
129. Fukamizo, T. Chitinolytic enzymes: Catalysis, substrate binding, and their application. Curr. Protein Pept. Sci. 2000, 1, 105-124. [CrossRef] [PubMed]

130. Horn, S.J.; Sorbotten, A.; Synstad, B.; Sikorski, P.; Sorlie, M.; Varum, K.M.; Eijsink, V.G. Endo/exo mechanism and processivity of family 18 chitinases produced by Serratia marcescens. FEBS J. 2006, 273, 491-503. [CrossRef] [PubMed]

131. Han, Y.; Yang, B.; Zhang, F.; Miao, X.; Li, Z. Characterization of antifungal chitinase from marine Streptomyces sp. DA11 associated with South China Sea sponge Craniella australiensis. Mar. Biotechnol. 2009, 11, 132-140. [CrossRef] [PubMed]

132. Stefanidi, E.; Vorgias, C.E. Molecular analysis of the gene encoding a new chitinase from the marine psychrophilic bacterium Moritella marina and biochemical characterization of the recombinant enzyme. Extremophiles 2008, 12, 541-552. [CrossRef] [PubMed]

133. Wang, S.L.; Liang, T.W.; Lin, B.S.; Wang, C.L.; Wu, P.C.; Liu, J.R. Purification and characterization of chitinase from a new species strain Pseudomonas sp. TKU008. J. Microbiol. Biotechnol. 2010, 20, 1001-1005. [PubMed]

134. Suginta, W.; Songsiriritthigul, C.; Kobdaj, A.; Opassiri, R.; Svasti, J. Mutations of Trp275 and Trp397 altered the binding selectivity of Vibrio carchariae chitinase A. Biochim. Biophys. Acta 2007, 1770, 1151-1160. [CrossRef] [PubMed]

135. De Assis, C.F.; Costa, L.S.; Melo-Silveira, R.F.; Oliveira, R.M.; Pagnoncelli, M.G.; Rocha, H.A.; De Macedo, G.R.; Santos, E.S. Chitooligosaccharides antagonize the cytotoxic effect of glucosamine. World J. Microbiol. Biotechnol. 2012, 28, 1097-1105. [CrossRef] [PubMed]

136. Chi, Z.; Zhang, T.; Liu, G.; Li, J.; Wang, X. Production, characterization and gene cloning of the extracellular enzymes from the marine-derived yeasts and their potential applications. Biotechnol. Adv. 2009, 27, $236-255$. [CrossRef] [PubMed]

137. Mba Medie, F.; Davies, G.J.; Drancourt, M.; Henrissat, B. Genome analyses highlight the different biological roles of cellulases. Nat. Rev. Microbiol. 2012, 10, 227-234. [CrossRef] [PubMed]

138. Gibbs, M.D.; Reeves, R.A.; Farrington, G.K.; Anderson, P.; Williams, D.P.; Bergquist, P.L. Multidomain and multifunctional glycosyl hydrolases from the extreme thermophile Caldicellulosiruptor isolate Tok7B.1. Curr. Microbiol. 2000, 40, 333-340. [CrossRef] [PubMed]

139. Bronnenmeier, K.; Kern, A.; Liebl, W.; Staudenbauer, W.L. Purification of Thermotoga maritima enzymes for the degradation of cellulosic materials. Appl. Environ. Microbiol. 1995, 61, 1399-1407. [PubMed]

140. Hakamada, Y.; Koike, K.; Yoshimatsu, T.; Mori, H.; Kobayashi, T.; Ito, S. Thermostable alkaline cellulase from an alkaliphilic isolate, Bacillus sp. KSM-S237. Extremophiles 1997, 1, 151-156. [CrossRef] [PubMed]

141. Lee, B.-H.; Kim, B.-K.; Lee, Y.-J.; Chung, C.-H.; Lee, J.-W. Industrial scale of optimization for the production of carboxymethyl cellulase from rice bran by a marine bacterium, Bacillus subtilis subsp. subtilis A-53. Enzyme Microb. Technol. 2010, 46, 38-42. [CrossRef]

142. Alfredsson, G.A.; Kristjansson, J.K.; Hjorleifsdottir, S.; Stetter, K.O. Rhodothermus marinus, gen. nov., sp. nov., a thermophilic, halophilic bacterium from submarine hot springs in iceland. J. Gen. Microbiol. 1988, 134, 299-306. [CrossRef]

143. Trivedi, N.; Gupta, V.; Kumar, M.; Kumari, P.; Reddy, C.R.K.; Jha, B. An alkali-halotolerant cellulase from Bacillus flexus isolated from green seaweed Ulva lactuca. Carbohydr. Polym. 2011, 83, 891-897. [CrossRef]

144. Fang, Z.; Fang, W.; Liu, J.; Hong, Y.; Peng, H.; Zhang, X.; Sun, B.; Xiao, Y. Cloning and characterization of a beta-glucosidase from marine microbial metagenome with excellent glucose tolerance. J. Microbiol. Biotechnol. 2010, 20, 1351-1358. [CrossRef] [PubMed]

(C) 2016 by the authors; licensee MDPI, Basel, Switzerland. This article is an open access article distributed under the terms and conditions of the Creative Commons Attribution (CC-BY) license (http://creativecommons.org/licenses/by/4.0/). 